\title{
ZAKUP KAO INSTITUT OBVEZNOG I STVARNOG PRAVA
}

Damir Kontrec, mag. iur., sudac

Vrhovni sud Republike Hrvatske
UDK: 347.25

Ur.: 26. veljače 2016.

Pr.: 10. ožujka 2016.

Stručni rad

\begin{abstract}
Sažetak
Ugovor o zakupu često se pojavljuje u praksi i spada među ugovore o privremenom prijenosu i korištenju dobara. Opće uređenje ugovora o zakupu propisuje Zakon o obveznim odnosima, dok s druge strane postoji niz posebnih propisa koji uređuju ugovore o zakupu posebnih vrsta stvari (poljoprivredno zemljište, poslovni prostor, brod). U radu se posebno ukazuje na sudsku praksu koja se bavi institutom zakupa, a posebno se govori o zakupu kao institutu stvarnog (zemljišnoknjižnog) prava.
\end{abstract}

Ključne riječi: Zakup, najam, ugovor o zakupu, poslovni prostor, poljoprivredno zemljište, zakup broda, obveze zakupodavca $i$ zakupnika, upis zakupa u zemljišnu knjigu.

\section{UVOD}

Ugovor o zakupu je, uz ugovor o prodaji (kupoprodaji), vjerojatno jedan od najčešćih ugovora koji se pojavljuju u praksi, pri čemu prema pravnoj teoriji spada u ugovore o privremenom prijenosu i korištenju dobara. ${ }^{1}$ Neki drugi autori stvrstavaju navedeni ugovor u ugovore o uporabi i korištenju stvari ${ }^{2}$. Iako se radi o teoretskim razlikama činjenica je da se zakupni odnosi nalaze svugdje oko nas, pa nam se čini bitnim obraditi ovaj institut kako s gledišta obveznoga prava, tako i s gledišta stvarnog prava i njegovih stvarnopravnih učinaka.

Zakupne odnose regulira cijeli niz propisa. Opće uređenje ugovora o zakupu propisuje Zakon o obveznim odnosima ${ }^{3}$, a posebna uređenja propisuju Zakon o

1 Vilim Gorenc, Loris Belanić, Hrvoje Momčinović, Ante Perkušić, Andrea Pešutić, Zvonimir Slakoper, Mario Vukelić, Branko Vukmir, Komentar Zakona o obveznim odnosima, Narodne novine, Zagreb, 2014., str. 869-908.

2 Petar Klarić, Martin Vedriš, Građansko pravo, Narodne novine, Zagreb, 2008., str. 515.

3 Narodne novine, br. 35/05, 41/08, 125/11, 78/15, dalje ZOO. 
zakupu i kupoprodaji poslovnog prostora ${ }^{4}$, Zakon o poljoprivrednom zemljištu Pomorski zakonik ${ }^{6}$, s time da neke odredbe o zakupu cestovnog zemljišta sadrži i Zakon o cestama ${ }^{7}$.

Posebno poglavlje posvećeno je zakupu kao institutu stvarnog, posebice zemljišnoknjižnog prava, s obzirom na to da se zakup kada je vezan uz nekretninu može upisati u zemljišnu knjigu.

\section{OPĆE UREĐENJE ZAKUPA PREMA ZAKONU O OBVEZNIM ODNOSIMA}

\subsection{Pojam i osnovne karakteristike ugovora o zakupu}

Opće uređenje ugovora o zakupu propisano je odredbama čl. 519. do 549., s time da se prema odredbi čl. 520. ZOO-a opće odredbe ZOO-a o ugovoru o zakupu neće primjenjivati na posebne vrste zakupa, osim podredno. To zapravo znači da će se odredbe ZOO-a o zakupu primjenjivati na posebne vrste zakupa ako posebnim propisima nije što drugo propisano.

Prema odredbi čl. 519. ZOO-a ugovor o zakupu je ugovor kojim se jedna ugovorna strana - zakupodavac obvezuje drugoj ugovornoj strani - zakupniku predati određenu stvar (treba tumačiti i pravo) na korištenje, a ta druga ugovorna strana dužna je za to plaćati naknadu - zakupninu. Iz navedene odredbe vidljivo je da su ugovorne strane ugovora o zakupu zakupodavac i zakupnik, da je predmet ugovora predaja određene stvari zakupodavca na korištenje zakupniku, te da postoji obveza zakupnika da zakupodavcu za to korištenje plaća određenu naknadu (zakupninu).

Prema različitim kriterijima ugovor o zakupu je:

- imenovani (nominatni) ugovor - naziv, sadržaj ugovora je određen i propisan (u konkretnom slučaju ZOO-om, ali i drugim propisima)

- naplatni (onerozni) ugovor - za činidbu (davanje stvari na korištenje) daje se određena protučinidba (zakupnina),

- dvostrani obvezni ugovor - obveza nastaje kako za zakupodavca (predaja stvari na korištenje), tako i zakupnika (plaćanje zakupnine),

- komutativni ugovor - da je već u vrijeme sklapanja ugovora poznat sadržaj činidbe i protučinidbe,

- neformalni ugovor - za uvjet valjanosti ugovora nije propisan poseban oblik ugovora,

- konsenzualni ugovor - prava i obveze stranaka nastaju njihovim sporazumom,

4 Narodne novine, br. 125/11, 64/15, dalje ZZKPP.

5 Narodne novine, br. 39/13, 48/15, dalje ZPZ.

6 Narodne novine, br. 181/04, 76/07, 146/08, 61/11, 56/13, 26/15, dalje PZ.

7 Narodne novine, br. 84/11, 22/13, 54/13, 148/13, 92/14, dalje ZC. 
- ugovor s trajnom obvezom - obveza traje dulje ili kraće vrijeme (ugovor o zakupu se sklapa na određeno ili neodređeno vrijeme),

- kauzalni ugovor - iz samog ugovora vidljiva je svrha sklapanja samog ugovor (korištenje određene stvari ili prava). ${ }^{8}$

Iz do sada iznesenog može se jasno zaključiti da su bitni sastojci ugovora o zakupu predmet zakupa i visina zakupnine, pa ugovor nastaje kada se ugovorne strane o tim bitnim elementima sporazumiju.

Predmet samog ugovora o zakupu može biti nekretnina, pokretnina, ali i pravo. Kod toga pojam nekretnine, odnosno pokretnine propisuje Zakon o vlasništvu i drugim stvarnim pravima ${ }^{9}$ čl. 2. st. 3. i 4. i čl. 9. ${ }^{10}$ Kod toga nije nužno da zakupodavac bude i vlasnikom predmeta zakupa, budući da je u sudskoj praksi zauzeto shvaćanje „da pravo vlasništva zakupodavca na stvari koju daje u zakup nije uvjet valjanosti ugovora o zakupu“11.

S druge pak strane kada se govori o zakupnini tada je u pravilu zakupnina određena u mjesečnom iznosu, ali moguće ju je odrediti i u drugim vremenskim razdobljima (tromjesečno, polugodišnje, godišnje ili kraće dnevno, tjedno). Kod toga visina zakupnine može biti i odrediva, na temelju elementa koje su stranke ugovorile, a isto tako moguće je ugovoriti da će se visina zakupnine mijenjati, primjerice ovisno o kretanju cijena na malo, o visini stope inflacije i slično. U praksi ipak najčešće nailazimo na slučajeve da se visina zakupnine točno odredi, u točno određenom novčanom iznosu, pri čemu se zna primijeniti valutna klauzula (protuvrijednost domaće valute u odnosu na euro). Vezano uz to u sudskoj praksi se ističe da „kad je obveza zakupnika na plaćanje zakupnine za poslovni prostor ugovorena uz valutnu klauzulu, zakupodavac ima potraživanje u stranoj valuti koji se ispunjava u domaćoj valuti“. ${ }^{12}$

Jedna od bitnih karakteristika ugovora o zakupu kao ugovora o privremenom prijenosu korištenja stvari je da zakupnik na predmetu zakupa ne stječe pravo vlasništva, za razliku primjerice od zajma gdje isti stječe pravo vlasništva na

8 Vilim Gorenc, Hrvoje Kačer, Hrvoje Momčinović, Zvonimir Slakoper, Branko Vukmir, Loris Belanić, Obvezno pravo, Posebni dio I., Pojedini ugovor, Novi informator, Zagreb, 2012., str. 152.-181.

9 Narodne novine, br. 91/96, 68/98, 137/99, 22/00, 73/00, 129/00, 114/01, 79/06, 141/06, $146 / 08,38 / 09,153 / 09,143 / 12,152 / 14$, dalje ZV.

10 Čl. 2. st. 3. i 4. ZV glasi: Nekretnine su čestice zemljine površine, zajedno sa svime što je sa zemljištem trajno spojeno na površini ili ispod nje, ako zakonom nije drukčije određeno (3). Pokretnine su stvari koje se mogu premjestiti s jednoga mjesta na drugo, a da im se ne povrijedi bit (supstanca). Stvari koje su po svojoj naravi pokretne stvari smatraju se u pravnom smislu nepokretnima ako su pripadak nepokretne stvari ili iz zakon izjednačuje s nekretninama (4).

Čl. 9. st. 1. ZV glasi: Pojedinačnu nekretninu čini zemljišna čestica, uključujući i sve što je s njom razmjerno trajno povezano na njezinoj površini ili ispod nje; ali kad je više zemljišnih čestica upisano u zemljišnoj knjizi u isti zemljišnoknjižni uložak, one su pravno sjedinjene u jedno tijelo (zemljišnoknjižno tijelo), koje je kao takvo jedna nekretnina.

11 VSRH, Rev-663/98 - www.sudskapraksa.vsrh.hr/supra

12 VSRH, Rev 3112/07-2 od 29.IV.2009. - www.ingbiro.com. 
pozajmljenim stvarima. Isto tako činjenica da je zakupnik dobio u posjed neku stvar znači da je isti neposredni posjednik stvari (čl. 10. st. 2. ZV), ali je s druge strane nesamostalni posjednik stvari (čl. 11. ZV). Stoga zakupnik kao nesamostalni posjednik nema uvjeta da bi dosjelošću stekao vlasništvo na predmetu zakupa ${ }^{13}$.

Uz plaćanje zakupnine moguća je situacija da zakupnik snosi i neke druge troškove, primjerice troškove poreza, zajedničke pričuve, no da bi to bila obveza zakupnika tada to mora biti ugovoreno.

U praksi se glede predmeta zakupa nalazi odluka prema kojoj „se na odnose stranaka iz ugovora o zakupu otvorenog sajmenog prostora ne primjenjuju odredbe Zakona o zakupu poslovnog prostora“. ${ }^{14}$ Jednako tako na ugovor o zakupu zemljišta ne primjenjuje se isti zakon, neovisno o tome što je na zemljištu postavljen montažni objek $\mathrm{t}^{15}$, već se u tim slučajevima primjenjuje odredbe ZOO-a.

\subsection{Oblik ugovora o zakupu}

ZOO polazi od načelne neformalnosti ugovora, pa te opće odredbe vrijede i za ugovor o zakupu. Posebnim propisima o zakupu poslovnog prostora određena je pisana forma ugovora. U nekim slučajevima se zahtijeva i da su potpisi ugovornih stranaka ovjereni. Kod toga treba razlikovati pisani oblik od ovjere potpisa jer pisani oblik predstavlja uvjet pravne valjanosti ugovora kada je to propisano, a ovjera potpisa je, primjerice, potrebna da bi se ugovor o zakupu mogao uknjižiti u zemljišnoj knjizi, kao posebna pretpostavka za upis, uz poseban uglavak kojim se dopušta uknjižba prava zakupa u zemljišnoj knjizi. ${ }^{16}$

\subsection{Obveze zakupodavca i zakupnika}

Već je rečeno da je ugovor o zakupu dvostranoobvezni ugovor, što znači da postoje obveze na obje ugovorne strane.

Kada se govori o osnovnim obvezama zakupodavca, tada se može reći da su to:

- obveza predaje predmeta zakupa zakupniku,

- obveza održavanja predmeta zakupa,

- obveza suzdržavanja od izmjena predmeta zakupa.

13 Čl. 159. ZV glasi: Dosjelošću se stječe vlasništvo stvari samostalnim posjedom te stvari ako taj ima zakonom određenu kakvoću i neprekidno traje zakonom određeno vrijeme, a posjednik je sposoban da bude vlasnikom te stvari (1). Samostalni posjednik čiji je posjed pokretne stvari zakonit, istinit i pošten, stječe je dosjelošću u vlasništvo protekom tri godine, a takav posjednik nekretnine protekom deset godina neprekidnoga samostalnog posjedovanja (2). Samostalni posjednik pokretne stvari kojemu je posjed barem pošten stječe je dosjelošću u vlasništvo protekom deset godina, a takav posjednik nekretnine protekom dvadeset godina neprekidnoga samostalnog posjedovanja (3).

14 VSRH, Rev 3123/99 od 29.I.2002. - www.ingbiro.com

15 VSRH, Rev 90/00 od 15.I.2002. - www.ingbiro.com

16 Gorenc, bilješka 8 , str. 159 . 
Prva i najznačajnija obveza zakupodavca je da predmet zakupa preda zakupniku i to u ispravnom stanju (stanju u kojem zakupnik taj predmet može koristiti u svrhu radi koje je zakup sklopljen), zajedno sa svim pripadcima. ${ }^{17} \mathrm{Ako}$ predmet zakupa ne bi bio predan zakupniku u ispravnom stanju, tada bi zakupodavac odgovarao zakupniku za materijalne nedostatke stvari. Ugovor o zakup djeluje između ugovornih strana, a ukoliko se radi o zakupu nekretnine (poslovnog prostora i slično) tada se učinak erga omnes postiže uknjižbom ugovora o zakupu u zemljišnoj knjizi. U sudskoj praksi je rečeno „da davanje u zakup dijela krova zgrade predstavlja posao redovite uprave, o čemu odlučuju suvlasnici većinom glasova“. ${ }^{18}$ No s druge strane ,davanje poslovnog prostora u zakup, posao je izvanredne uprave za koji je potrebna suglasnost svih suvlasnika, pa je suvlasnik koji nije dao potrebnu suglasnost ovlašten tražiti iseljenje zakupnika“". ${ }^{19}$

Daljnja obveza zakupodavca je da predmet zakupa održava u ispravnom stanju, stanju koje je podobno za ugovoreni način korištenja predmeta zakupa. Kod toga je zakupodavac dužan zakupniku nadoknaditi troškove koje je isti imao u svezi s održavanjem predmeta zakupa, a koje bi i inače trebao učiniti sam zakupodavac. Ako se radi o troškovi sitnih popravaka izazvanih redovitim korištenjem stvari, takvi troškovi padaju na teret zakupnika (primjerice troškove izmjene žarulja za struju i slični troškovi). No, u svakom slučaju je zakupnik o potrebi popravka dužan obavijestiti zakupodavca. ${ }^{20}$

Isto tako zakupodavac se dužan suzdržavati od vršenja bilo kakvih izmjena na predmetu zakupa, a zbog kojih bi zakupnik bio ometan u uporabi ili korištenju tog predmeta. No, ako bi izmjenama, na koje je zakupnik pristao, bila smanjena mogućnost korištenja predmeta zakupa, tada bi zakupnik imao pravo na smanjenje zakupnine u odgovarajućem razmjeru. ${ }^{21}$

S druge strane temeljne obveze zakupnika su:

- obveza korištenja predmeta zakupa u skladu s ugovorom,

- obveza snošenja troškova redovite uporabe predmeta zakupa,

- obveza snošenja troškova sitnih popravaka predmeta zakupa,

- obveza plaćanja zakupnine,

- obveza vraćanja predmeta zakupa,

- obveza obavješćivanja zakupodavca o nepredviđenim opasnostima.

Potpuno je jasno da zakupnik ima pravo koristiti stvari u skladu s ugovorom i to kao dobar gospodarstvenik, odnosno kao dobar domaćin, ovisno o svojstvima zakupnika. Zakupnik koji obavlja registriranu djelatnost, obrtnik mora koristiti predmeta zakupa kao dobar gospodarstvenik, dakle s povećanom pažnjom, dok se za ostale osobe zahtijeva korištenje u skladu s pažnjom dobrog domaćina, dakle onako kako bi se zakupnik koristio da se koristi vlastitom stvari. Bitno je da zakupnik stvar

17 Čl. 521. ZOO.

18 ŽS Zagreb, Gž-246/02 od 21.X.2003. - www.ingbiro.com

19 VSRH, Rev 619/98 - www.sudskapraksa.vsrh.hr/supra

20 Čl. 522. st. 2., 3. i 4. ZOO.

21 Čl. 524. ZOO. 
koristi u skladu s ugovorenom namjenom, pa ako bi koristio stvar protivno namjeni ili protivno ugovoru pa nekome nastane šteta, za istu odgovara zakupnik. ${ }^{22}$

Isto tako potpuno je razumljivo da troškove korištenja predmeta zakupa, primjerice troškove energije koja se koristi u poslovnom prostoru ili trošak goriva u zakupljenom vozilu, snosi zakupnik, jednako kao što isti snosi i troškove sitnih popravaka. Je li neki popravak sitan ili ne, činjenično je pitanje (questio facti) svakog konkretnog slučaja. Tu bi uvijek trebalo imati na umu kolika je visina zakupnine, koliki je iznos troškova popravka, koja je važnost popravka za nastavak ugovora o zakupu i slično.

Vjerojatno najznačajnija obveza zakupnika je plaćanje zakupnine i to u rokovima određenim ugovorom ili zakonom, odnosno ako njima to nije ugovoreno, tada kako je to uobičajeno u mjestu gdje je stvar predana zakupniku. ZOO sadrži dispozitivne odredbe i daje mogućnost da ako nije drugačije ugovoreno ili nije uobičajeno, da se tada zakupnina plaća polugodišnje kad je stvar dana u zakup za jednu ili više godina, a ako je dana za kraće vrijeme, tada se zakupnina plaća nakon isteka tog vremena. ${ }^{23}$ Neplaćanje zakupnine ujedno predstavlja razlog za otkaz ugovora o zakupu.

Daljnja obveza zakupnika je da vrati predmet zakupa zakupodavcu i to neoštećen, s time da se vraćanje vrši u mjestu u kojem je predmet zakupa bio predan zakupniku. ${ }^{24}$ Kod toga zakupnik ne odgovara za uobičajenu istrošenost predmeta zakupa koja je nastala redovitom uporabom, kao ni za oštećenja koja potječu do dotrajalosti. Iz navedenog bi se moglo zaključiti da je obveza zakupnika da čuva predmet zakupa tijekom cijelog trajanja zakupa sve dok predmet zakupa ne bude ponovno vraćen zakupodavcu. Pravo je zakupnika da odnese određene dodatke predmeta zakupa, koji se od njega mogu odvojiti bez da uništi predmet zakupa ili isti ošteti. Primjerice ako je zakupnik u automobil ugradio navigacijski uređaj, taj uređaj zakupnik ima pravo uzeti nakon prestanka ugovora o zakupu, s time da zakupodavac može to zadržati ako zakupniku naknadi vrijednost takvog dodatka u vrijeme vraćanja. Kod toga „bespravno korištenje tuđeg zemljišta nakon prestanka zakupa daje pravo vlasniku na naknadu izmakle koristi““. ${ }^{25}$ No s druge strane „osobi koja je na zakupljenom neizgrađenom građevinskom zemljištu u društvenom vlasništvu postavila kiosk, kao privremeni objekt, i koja je po isteku zakupa dužna ukloniti taj objekt, ne pripada pravo na naknadu ulaganja u svezi s postavljanjem kioska". 26

Zadnja bitna obveza zakupnika je da zakupodavca obavijesti o nedostacima i opasnostima. Tako je zakupnik dužan zakupodavca obavijestiti o svakom nedostatku zakupljene stvari i to bez odgađanja, osim ako za taj nedostatak zakupodavca zna. Isto vrijedi ako postoji neka nepredviđena opasnost koja bi prijetila zakupljenoj

22 Čl. 532. ZOO.

23 Čl. 534. ZOO.

24 Čl. 536. ZOO.

25 VSRH, Rev-638/06-2 od 28.VI.2006. - www.ingbiro.com.

26 VSRH, Rev-638/06-2 od 28.VI.2006. - www.ingbiro.com. 
stvari, kako bi zakupodavac mogao poduzeti na vrijeme radnje kojima bi tu opasnost otklonio. Ako zakupnik ne bi obavijestio zakupodavca o uočenom nedostatku ili o nastaloj opasnosti, za koje zakupodavac nije znao, tada zakupnik gubi pravo na naknadu štete koju bi pretrpio zbog postojanja nedostatka ili nastale opasnosti, a ujedno bi zakupnik bio dužan naknaditi štetu zakupodavcu.

\subsection{Odgovornost za nedostatke}

Kada se govori o zakupodavčevoj odgovornosti za pravne nedostatke, tada valja istaknuti da se na odgovornost za pravne nedostatke na odgovarajući način primjenjuju pravila o odgovornosti prodavatelja za pravne nedostatke prodane stvari (čl. 430. do 437. ZOO). O pravnom nedostatku predmeta zakupa govorimo kada netko treći na zakupljenoj stvari ili na nekom njezinom dijelu polaže neko pravo. U tom slučaju ako se treći sa svojim zahtjevom obrati zakupniku ili ako samovlasno oduzme predmet zakupa od zakupnika, zakupnik je o tome dužan izvijestiti zakupodavca, osim ako zakupodavac to zna. U protivnom ta treća osoba može odgovarati za štetu. ${ }^{27}$

Ako bi se utvrdilo da trećemu pripada neko pravo koje sasvim isključuje zakupnika od korištenja stvari koja je bila predmetom zakupa, tada dolazi do raskida ugovora o zakupu ex lege, a zakupodavac je dužan u tom slučaju naknaditi štetu zakupniku. Ako pravo trećeg samo ograničava zakupnikovo pravo, tada isti može, po svom izboru, ili raskinuti ugovor o zakupu ili zahtijevati sniženje zakupnine, a u svakom slučaju ima pravo na naknadu štete ako je nastala. U praksi je tako navedeno da „okolnost da je ugovor o zakupu poslovnog prostora kao zakupodavac neovlašteno sklopila osoba koja nije vlasnik, nije razlog ništavosti ugovora, već odgovornosti za pravne nedostatke“..$^{28}$

Moguća je situacija da predmet zakupa ima neki materijalni nedostatak. U tom slučaju ako u času predaje zakupljena stvar ima neki nedostatak koji se ne može otkloniti, zakupnik ima pravo po svom izboru ili raskinuti ugovor ili zahtijevati sniženje zakupnine. Ako je u pitanju nedostatak koji se može otkloniti bez nekih većih nezgoda za zakupnika, a predaja stvari o roku nije bitan sastojak ugovora, tada zakupnik ima pravo zahtijevati od zakupodavca otklanjanje nedostatka u primjerenom roku ili sniženje zakupnine. Ako zakupodavac ne bi otklonio nedostatak u naknadnom primjerenom roku, tada bi zakupnik imao pravo raskinuti ugovor o zakupu ili zahtijevati sniženje zakupnine, a u svakom slučaju ima pravo na naknadu štete. Ova se pravila primjenjuju i kada nedostatak nastane za vrijeme trajanja ugovora o zakupu, kao i kad stvar nema neko svojstvo koje je po ugovoru trebala imati ili je to izgubila tijekom zakupa.

27 Čl. 531. ZOO.

28 VSRH, Rev 885/07-2 od 19.XII.2007. - www.ingbiro.com. 


\subsection{Posljedice neizvršavanja ili neurednog izvršavanja ugovornih obveza}

Vjerojatno najčešći razlog neizvršavanja ugovornih obveza kod ugovora o zakupu u praksi predstavlja neplaćanje zakupnine, odnosno neuredno plaćanje zakupnine. Da bi zbog neplaćanja zakupnine došlo do otkaza ugovora o zakupu potrebno je da zakupodavac prethodno pozove zakupnika da plati dospjelu neplaćenu zakupninu, pa ako to zakupnik ne učini niti u roku od 15 dana od dana poziva na plaćanje, tada zakupodavac ima pravo otkazati ugovor o zakupu. No, niti u tom slučaju neće doći do otkaza ako bi zakupnik platio dospjele iznose zakupnine prije nego što mu bude priopćen otkaz ugovora o zakupu. ${ }^{29}$

Drugi slučaj neurednog izvršavanja ugovornih obveza predstavlja kada zakupnik koristi predmet zakupa protivno ugovoru, odnosno protivno namjeni same stvari (predmeta zakupa). U tim slučajevima zakupodavac ima pravo otkazati ugovor o zakupu te tražiti eventualno naknadu štete, ako je ista nastala.

Jednako tako i zakupnik ima pravo jednostrano otkazati ugovor o zakupu. Tako ako je potrebno vršiti popravke na predmetu zakupa i ti popravci ometaju zakupnika u korištenju predmeta zakupa u znatnoj mjeri i dulje vrijeme, zakupnik ima pravo raskinuti ugovor, ali isto tako ima pravo tražiti razmjerno sniženje zakupnine. ${ }^{30}$

\subsection{Podzakup}

Temeljno je pravilo da zakupnik može zakupljenu stvar dati u podzakup, ako nije drugačije ugovoreno, ali samo ako se time ne nanosi šteta zakupodavcu. $U$ slučaju podzakupa zakupnik jamči zakupodavcu da će podzakupnik koristiti stvar prema ugovoru o zakupu. ${ }^{31}$ Iz tako stilizirane odredbe jasno proizlazi da kada je ugovorom o zakupu zabranjeno davati stvar u podzakup (ili je to zabranjeno propisom) tada davanje stvari u podzakup od strane zakupnika predstavlja razlog za raskid ugovora o zakupu. ${ }^{32} \mathrm{U}$ tom slučaju zakupodavac ugovor o zakupu može jednostrano raskinuti ugovor o zakupu izjavom o otkazu ugovora o zakupu.

Ako je stvar dana u podzakup, zakupodavac ima pravo radi naplate svojih potraživanja koje ima prema zakupniku nastalih iz ugovora o zakupu zahtijevati neposredno od podzakupnika isplatu iznosa koje bi podzakupnik trebao platiti zakupniku na temelju podzakupa. ${ }^{33}$

No, u svakom slučaju podzakup prestaje kada prestane ugovor o zakupu..$^{34} \mathrm{O}$ tome se potpuno jasno izjasnila i sudska praksa da ,prestankom ugovora o zakupu prestaje i ugovor o podzakupu. ${ }^{“ 35} \mathrm{~S}$ druge strane ,Zakupodavac je ovlašten radi

29 Čl. 535. ZOO.

30 Čl. 523. ZOO.

31 Čl. 537. ZOO.

32 Čl. 538. ZOO.

33 Čl. 539. ZOO.

34 Čl. 540. ZOO.

35 VSRH, Rev 1383/07-2 od 18.III.2008. - www.ingbiro.com. 
naplate svojih potraživanja od zakupnika nastalih iz zakupa, zahtijevati neposredno od podzakupnika isplatu iznosa koje ovaj duguje zakupniku po osnovi podzakupa“. ${ }^{36}$

\subsection{Založno pravo i pravo zadrăanja}

Kod ugovora o zakupu ne predviđa se da bi zakupodavac imao pravo zaloga, odnosno pravo retencije (zadržanja) kako je to propisano kod ugovora o najmu u čl. 565. ZOO-a. U sudskoj praksi se tako navodi „da pravo zadržanja automobila ne pripada zakupodavcu na temelju ugovora koji mu ne daje pravo na posjed automobila“. 37

\subsection{Otuđenje predmeta zakupa}

Kada se govori o otuđenju predmeta zakupa, mogu se razlikovati dvije situacije: prva, da je do otuđenja predmeta zakupa došlo nakon predaje stvari u zakupu i druga, da je do otuđenja došlo prije predaje predmeta zakupa zakupniku.

U prvom slučaju ako do otuđenja predmeta zakupa dođe nakon što je zakupniku predan predmet zakupa, pribavitelj (novi stjecatelj predmeta zakupa) stupa na mjesto zakupodavca i nakon toga prava i obveze iz zakupa nastaju između njega i zakupnika. Pribavitelj nema pravo tražiti od zakupnika da mu preda stvar prije proteka vremena na koje je zakup ugovoren, ako trajanje zakupa nije određeno ni ugovorom ni zakonom, onda ne prije isteka otkaznog roka. Pritom za pribaviteljeve obveze iz zakupa prema zakupniku odgovara prenositelj kao solidarni jamac..$^{38}$ Iz navedenog je jasno vidljivo da se u tom slučaju štiti zakupnik i njegov pravni položaj.

U slučaju kada do otuđenja zakupljene stvari dođe prije predaje predmeta zakupa zakupniku, dakle kada je predmet zakupa predan prije pribavitelju nego zakupniku, i u tom slučaju pribavitelj stupa na mjesto zakupodavca i preuzima sve njegove obveze prema zakupniku, ako je u trenutku sklapanja ugovora o otuđenju znao za postojanje ugovora o zakupu. Dakle, bitno je, je li pribavitelj znao da je sklopljen ugovora o zakupu ili ne. Ako je znao, tada se štiti zakupnik i pribavitelj stupa u pravni položaj zakupodavca. Ako pribavitelj u trenutku sklapanja ugovora nije znao za postojanje ugovora o zakupu, tada isti nije dužan predati predmet zakupa zakupniku, znači štiti se pribavitelj, a zakupnik ima jedino pravo tražiti naknadu štete od zakupodavca. I u ovom slučaju za pribaviteljeve obveze iz zakupa prema zakupniku odgovara prenositelj kao solidarni jamac. ${ }^{39}$

U sudskoj praksi je tako odlučeno da ,ako nakon otuđenja nekretnine dane u zakup novi vlasnik, koji stupa u prava i obveze iz ranije zaključenog ugovora o zakupu, i zakupac te nekretnine nisu izmijenili odredbu (dopuštenu) ugovora o

36 VTSRH, Pž-2453/92 od 11.V.1993. - www.ingbiro.com.

37 VSRH, Rev 2454/95 od 6.V.1999. - www.ingbiro.com.

38 Čl. 542. ZOO.

39 Čl. 543. ZOO. 
načinu plaćanja zakupnine u naturi (isporukom 5 tona kukuruza u zrnu), onda novi zakupodavac nije ovlašten od zakupca tražiti ispunjenje njegove obveze isplatom novčanog iznosa - vrijednosti ugovorene količine kukuruza. “40

Pravo je zakupnika da u slučaju otuđenja predmeta zakupa otkaže ugovor o zakupu, poštujući pritom zakonske otkazne rokove. ${ }^{41}$

\subsection{Prestanak ugovora o zakupu}

Kada se govori o prestanku ugovora o zakupu, tada razlikujemo sljedeće načine prestanka:

- protekom vremena,

- otkazom,

- propašću predmeta zakupa.

Već je rečeno da postoji ugovor o zakupu na određeno vrijeme, pa takav ugovor prestaje protekom vremena na koje je ugovor o zakupu sklopljen. Stoga nakon isteka ugovora o zakupu na određeno vrijeme u parnici radi isplate zakupnine, zakupnina se više ne bi mogla tražiti nakon proteka vremena na koje je ugovor o zakupu sklopljen, već bi se nakon toga vremena mogla samo tražiti naknada u visini zakupnine.

Vezano uz ugovor o zakupu na određeno vrijeme je i pitanje prešutnog obnavljanja zakupa. Naime, ako nakon proteka vremena za koje je ugovor o zakupu sklopljen zakupnik nastavi koristiti stvar, a zakupodavac se tome ne usprotivi, smatra se da je prešutno sklopljen novi ugovor o zakupu, ali sada na neodređeno vrijeme, pod istim uvjetima kao i raniji ugovor koji je istekao. Ako su treće osobe za raniji ugovor o zakupu dale kakvo osiguranje, tada osiguranja prestaju kada prestane ranije ugovor o zakupu. ${ }^{42}$ Vezano uz prešutno obnavljanje ugovora $\mathrm{o}$ zakupu u sudskoj praksi je izraženo shvaćanje ,iako se prema čl. 546. ZOO ugovor o zakup sklopljen na određeno vrijeme smatra prešutno obnovljenim na neodređeno vrijeme ako zakupac nastavi koristiti stvar, a zakupodavac se tome ne protivi, takav prešutno obnovljeni ugovor nema svojstvo ovršne isprave““.43

Drugi način prestanka ugovora o zakupu propisan je za ugovor o zakupu čije trajanje nije određeno niti se može odrediti iz okolnosti ili mjesnih običaja. U tim slučajevima ugovor o zakupu prestaje otkazom, pri čemu je zakupodavac taj koji mora dati otkaz zakupnik i kod toga poštivati otkazni rok. Glede duljine trajanja otkaznog roka ugovorne strane imaju pravo same odrediti isti, no ako duljina trajanja otkaznog roka nije određena ugovorom niti zakonom ili mjesnim običajima, tada otkazni rok traje osam dana, s time da se otkaz ne može dati u nevrijeme. O tome je li otkaz dan u nevrijeme činjenično je pitanje i ovisi o okolnostima svakog

40 ŽS Bjelovar, Gž-2776/11-2 od 24.V.2012. - www.ingbiro.com.

41 Čl. 544. ZOO.

42 Čl. 546. ZOO.

43 ŽS Dubrovnik, Gž-1567/08 od 25. IX.2008. - www.ingbiro.com. 
konkretnog slučaja. ${ }^{44}$ „Kad se otkazuje ugovor o zakupu zbog neplaćanja zakupnine potrebno je poštovati otkazni rok“" ${ }^{45}$

Treći način prestanka ugovora o zakupu je propast stvari, s time da se kod ugovora o zakupu mora raditi o propasti stvari uslijed više sile. Tako u slučaju da stvar (predmet zakupa) bude uništena u potpunosti, ugovor o zakupu prestaje, a ako stvar bude djelomično uništena ili samo oštećena, pravo je zakupnika da u tom slučaju raskine ugovor o zakupu ili da dalje ostane u zakupnom odnosu i zahtijeva sniženje zakupnine. ${ }^{46}$

Smrt bilo zakupnika, bilo zakupodavca ne utječe na postojanje ugovora o zakupu, jer se zakup nastavlja s nasljednicima jedne ili druge strane, osim ako u samom ugovoru o zakupu ne bi bilo što drugo ugovoreno. ${ }^{47}$

„Za suđenju u sporu iz trgovačkog ugovora o zakupu između osoba koje obavljaju gospodarsku djelatnost nadležan je trgovački sud.“"48

\section{POSEBNA UREĐENJA ZAKUPA PREMA POSEBNIM PROPISIMA}

\subsection{Zakup poslovnog prostora}

Posebne odredbe o zakupu i to poslovnih prostorija sadrži Zakon o zakupu i kupoprodaji poslovnog prostora ${ }^{49,50}$. Prema odredbi čl. 2. st. 3. ZZKPP-a poslovnim se prostorom u smislu toga Zakona smatraju poslovna zgrada, poslovna prostorija, garaža i garažno mjesto. U st. 4. istog članka definirano je da se poslovnom zgradom smatra zgrada namijenjena obavljanju poslovne djelatnosti ako se pretežitim dijelom i koristi u tu svrhu. Prema st. 5. poslovnom prostorijom smatra se jedna ili više prostorija u poslovnoj ili stambenoj zgradi namijenjena obavljanju poslovne djelatnosti koja, u pravilu, čini samostalnu uporabnu cjelinu i ima zaseban glavni ulaz. Garaža je prostor za smještaj vozila (st. 6.), dok je garažno mjesto prostor za smještaj vozila u garaži (st. 7.).

Naime, ako se govori o poslovnoj prostoriji, garaži ili garažnom mjestu, tada se $u$ tom slučaju mora raditi o posebnom dijelu nekretnine $\mathrm{i}$ ako je taj poseban dio nekretnine upisan u zemljišnu knjigu, tada bi se zakup mogao upisati kao teret tog određenog posebnog dijela nekretnine. Odredbom čl. 66. st. 1. ZV-a propisano je

44 Čl. 547. ZOO.

45 ŽS Dubrovnik, Gž-1216/04 od 16.VI.2005. - www.ingbiro.com.

46 Čl. 548. ZOO.

47 Čl. 549. ZOO.

48 VSRH, Gr1 356/07-2 od 24.IX.2007. - www.ingbiro.com

49 Kontrec Damir, Novine u zakupu i kupoprodaji poslovnog prostora, Zbornik Pravnog fakulteta Sveučilišta u Rijeci (1991), v. 33, br. 1, str. 461-483.

50 O ranijem Zakonu o zakupu i prodaji poslovnog prostora i sudskoj praksi uz taj Zakon, vidi u: Brežanski Jasna, Barjaktar Biljana, Đikandić Desanka - Najam stanova i zakup poslovnog prostora u praksi, Novi informator, Zagreb, 2006. 
da vlasništvo određenoga posebnog dijela nekretnine (etažno vlasništvo) proizlazi i ostaje neodvojivo povezano s odgovarajućim suvlasničkim dijelom (idealnim dijelom) nekretnine na kojem je uspostavljeno. U st. 3. je određeno da vlasništvo posebnoga dijela može biti uspostavljeno na odgovarajućem suvlasničkom dijelu nekretnine koja se sastoji od zemljišta sa zgradom ili od prava građenja sa zgradom. U čl. 67. st. 1. i 2. ZV-a određeno je da vlasništvo posebnoga dijela može biti uspostavljeno glede dijela suvlasničke nekretnine koji čini samostalnu uporabnu cjelinu, prikladnu za samostalno izvršavanje suvlasnikovih ovlasti, kao što je stan ili druga samostalna prostorija, a u druge samostalne prostorije osobito spadaju samostalne poslovne prostorije, samostalne garaže ili jasno omeđena mjesta u zgradi namijenjena ostavljanju motornih vozila. ${ }^{51}$

Novi ZZKPP iz 2011. godine uređuje zasnivanje i prestanak zakupa poslovnog prostora te međusobna prava i obveze zakupodavca i zakupnika, kao i kupoprodaju poslovnoga prostora u vlasništvu Republike Hrvatske, županije, Grada Zagreba, grada ili općine - jedinica lokalne i područne (regionalne) samouprave ${ }^{52}$. Pod kupoprodajom poslovnoga prostora podrazumijeva se i prodaja suvlasničkog dijela na određenom poslovnom prostoru, odnosno predmetom kupoprodaje mogu biti i poslovni prostori, koji u smislu Zakona o zaštiti i očuvanju kulturnih dobara ${ }^{53}$ imaju svojstvo kulturnog dobra, pod uvjetima propisanim u tom Zakonu. Treba dodati da se na zakupne odnose koji nisu uređeni ovim zakonom primjenjuju opći propisi obveznoga prava o zakupu, dok se odredbe Zakona ne primjenjuju na slučajeve privremenoga korištenja poslovnoga prostora ili dijela poslovnoga prostora radi održavanja sajmova, priredaba, predavanja, savjetovanja, skladištenja i čuvanja robe ili u druge slične svrhe, a koje korištenje ne traje duže od 30 dana.

S obzirom na navedeno može se zaključiti da ZZKPP dosljedno prati određenje $\mathrm{ZV}$-a o tome što može biti poseban dio nekretnine.

51 Potrebnim nam se čini ukazati na nepravilnu praksu, gdje se kao samostalne uporabne cjeline, kao samostalne etaže utvrđuju i parkirna mjesta na otvorenom, takva parkirna mjesta na otvorenom znaju se prodavati osobama koje nemaju vlasništvo posebnog dijela u zgradi koja se nalazi na toj parceli, a što je u potpunosti u protivnosti s određenje etažnog vlasništva odnosno vlasništva posebnog dijela nekretnine prema odredbama ZV-a. Prema odredbi čl. 67. st. 3. ZV-a uz stan odnosno drugu samostalnu prostoriju, vlasništvo posebnoga dijela nekretnine može se protezati i na sporedne dijelove kao što su otvoreni balkoni, terase, podrumske ili tavanske prostorije, kućni vrtovi, mjesta za ostavljanje najviše do dva motorna vozila po pojedinom stanu ili drugoj samostalnoj prostoriji.

52 Čl. 1. st. 1. ZZKPP.

53 Narodne novine, br. 66/99, 151/03, 157/03, 100/04, 87/09, 88/10, 61/11. U smislu čl. 2. st. 2. Zakona o zaštiti i očuvanju kulturnih dobara, pod kulturnim dobrima u smislu tog Zakona su: - pokretne i nepokretne stvari od umjetničkoga, povijesnoga, paleontološkoga, arheološkoga, antropološkoga i znanstvenoga značenja,

- arheološka nalazišta i arheološke zone, krajolici i njihovi dijelovi koji svjedoče o čovjekovoj prisutnosti u prostoru, a imaju umjetničku, povijesnu i antropološku vrijednost,

- nematerijalni oblici i pojave čovjekova duhovnog stvaralaštva u prošlosti kao i dokumentacija i bibliografska baština i

- zgrade, odnosno prostori u kojima se trajno čuvaju ili izlažu kulturna dobra i dokumentacija o njima. 
Gradska skupština Grada Zagreba, odnosno gradsko ili općinsko vijeće imaju ovlast svojom odlukom propisati da se poslovni prostor u zgradama u vlasništvu Grada Zagreba, grada ili općine, a koje se nalaze u određenim ulicama, dijelovima ulica ili na određenim trgovima može koristiti za obavljanje samo određenih djelatnosti. Ako se radi o tradicijskim ili deficitarnim zanimanjima, tada nadležna skupština odnosno vijeće prije donošenja odluke treba pribaviti mišljenje udruženja obrtnika ili područne obrtničke komore ${ }^{54}$. Namjera je zakonodavca da se sačuvaju određena tradicijska ili deficitarna zanimanja, pri čemu se ograničenje odnosi na poslovne prostore u vlasništvu Grada Zagreba, općine ili grada.

Zakup poslovnog prostora zasniva se ugovorom o zakupu (čl. 4. st. 1. ZZKPP), pri čemu ugovor mora biti sastavljen u pisanom obliku (st. 3. istog članka). Zbog problema u praksi i činjenice da su prostori u zakupu osoba koje ne ispunjavaju svoje obveze prema državnom proračunu, odnosno jedinicama lokalne i područne (regionalne) samouprave, zakonodavac je u čl. 4. st. 2. propisao da ugovor o zakupu poslovnog prostora Republika Hrvatska, odnosno jedinica lokalne i područne (regionalne) samouprave ne može sklopiti s fizičkom ili pravnom osobom koja ima dospjelu nepodmirenu obvezu prema državnom proračunu i jedinicama lokalne i područne (regionalne) samouprave, osim ako je sukladno posebnim propisima odobrena odgoda plaćanja navedenih obveza, pod uvjetom da se fizička ili pravna osoba pridržava tih rokova. U slučaju ako je zakupodavac Republika Hrvatska odnosno jedinica lokalne i područne (regionalne) samouprave, tada ugovor o zakupu mora biti potvrđen (solemniziran) po javnom bilježniku (st. 3.). Posljedica da je ugovor o zakupu sklopljen protivno gore navedenim ograničenjima iz st. 2. i 3. predstavlja ništetan ugovor. ${ }^{55}$

54 Čl. 3. ZZKPP.

55 O ništetnim ugovorima ZOO propisuje:

Čl. 322. ZOO glasi: Ugovor koji je protivan Ustavu Republike Hrvatske, prisilnim propisima ili moralu društva ništetan je, osim ako cilj povrijeđenog pravila ne upućuje na neku druge pravnu posljedicu ili ako zakon u određenom slučaju ne propisuje što drugo (st. 1.) Ako je sklapanje određenog ugovora zabranjeno samo jednoj strani, ugovor je valjan ako u zakonu nije što drugo predviđeno za određeni slučaj, a strana koja je povrijedila zakonsku zabranu snosit će odgovarajuće posljedice (st. 2.).

Čl. 323. ZOO: U slučaju ništetnosti ugovora svaka ugovorna strana dužna je vratiti drugoj sve ono što je primila na temelju takva ugovora, a ako to nije moguće, ili se narav onoga što je ispunjeno protivi vraćanju, ima se dati odgovarajuća naknada u novcu, prema cijenama u vrijeme donošenja sudske odluke, ako zakon što drugo ne određeuje (st. 1.). Ugovaratelj koji je kriv za sklapanje ništetnog ugovora odgovoran je svome suugovaratelju za štetu koju trpi zbog ništetnosti ugovora ako ovaj nije znao ili prema okolnostima nije morao znati za postojanje uzroka ništetnosti (st. 2.).

Čl. 324. ZOO: Ništetnost neke odredbe ugovora ne povlači ništetnost ugovora ako on može postati bez ništetne odredbe i ako ona nije bila ni uvjet ugovora niti odlučujuća pobuda zbog koje je ugovor sklopljen (st. 1.). Ali će ugovor ostati valjan čak i ako je ništetna odredba bila uvjet ili odlučujuća pobuda ugovora u slučaju kad je ništetnost ustavljena upravo da bi ugovor bio oslobođen te odredbe i vrijedio bez nje (st.2.).

Čl. 325. ZOO: Kad ništetan ugovor udovoljava pretpostavkama za valjanost nekog drugog ugovora, onda će među ugovarateljima vrijediti taj drugi ugovor, ako bi to bili u suglasnosti s 
U svakom slučaju obveza je zakupodavca da primjerak ugovora o zakupu dostavi nadležnoj poreznoj upravi.

Ugovorom o zakupu poslovnog prostora obvezuje se zakupodavac predati zakupniku određeni poslovni prostor na korištenje, a zakupnik se obvezuje platiti mu za to ugovorenu zakupninu. ${ }^{56}$ Ugovor o zakupu mora sadržavati:

1. naznaku ugovornih strana,

2. podatke o poslovnom prostoru,

3. djelatnost koja će se obavljati u poslovnom prostoru,

4. odredbe o korištenju zajedničkih uređaja i prostorija u zgradi,

5. rok predaje poslovnoga prostora zakupniku,

6. vrijeme na koje je ugovor sklopljen,

7. iznos zakupnine,

8. pretpostavke i način izmjene zakupnine,

9. mjesto i vrijeme sklapanja ugovora.

Bez obzira što u ZZKPP više nema odredbe koja regulira pitanje rokova plaćanja zakupnine, odnosno naknade za korištenje zajedničkih uređaja zgrade, čini nam se da to bilo potrebno unijeti u ugovor o zakupu. Tim više što ugovor o zakupu, kada ga sklapa Republika Hrvatska, odnosno jedinica lokalne i područne (regionalne) samouprave mora biti solemniziran ${ }^{57}$ po javnom bilježniku. Isto

ciljem koji su ugovaratelji imali na umu kad su ugovor sklopili i ako se može uzeti da bi oni sklopili taj ugovor da su znali za ništetnost svog ugovora.

Čl. 326. ZOO: Ništetan ugovor ne postaje valjan kad uzrok ništetnosti naknadno nestane (st.1.). Ali ako je uzrok ništetnosti bila zabrana manjeg značenja, a ugovor u cijelosti ispunjen, ništetnost se ne može isticati (st. 2.).

Čl. 327. ZOO: Na ništetnost sud pazi po službenoj dužnosti i na nju se može pozivati svaka zainteresirana osoba (st. 1.). Pravo zahtijevati utvrđenje ništetnosti ima i državni odvjetnik (st. 2.).

Čl. 328. ZOO: Pravo na isticanje ništetnosti ne gasi se.

56 Čl. 5. ZZKPP.

57 Zakon o javnom bilježništvu, Narodne novine, br. 78/93, 29/94, 162/98, 16/07, 75/09, dalje ZJB, u čl. 59. propisuje potvrda (solemnizaciju) privatnih isprava: Ako nisu u pitanju pravni poslovi iz čl. 53. ovoga Zakona, sudionici u pravnom poslu, svi ili neki od njih, mogu isprave o pravnom poslu potvrditi kod javnog bilježnika. Za zasnivanje osiguranja tražbine uređene zakonom, dovoljno je da privatnu ispravu potvrdi obveznik. Potvrđena isprava ima snagu javnobilježničkog akta, a ako je sastavljena po propisima članka 54. ovoga Zakona ima snagu i ovršnog javnobilježničkog akta (st. 1.). Javni će bilježnik privatnu ispravu ispitati u skladu s odredbama članka 34., 57. i 58. ovoga Zakona i ako za to ne nađe zapreke potvrdit će je (st. 2.). Ako privatna isprava odgovara po svom obliku propisima javnobilježničke isprave (čl. 43. do 48.) i propisima o sadržaju javnobilježničkog akta (čl. 69. st. 1. tč. 2., 4. i 6.), te ako su ju potpisali sudionici iz članka 69. stavka 1. točke. 2. ovoga Zakona, ona će se potvrditi bez sastavljanja posebnog javnobilježničkog akta na taj način što će se na ispravu staviti posvjedočenja navedena u čl. 69. točki 1., 3. i 5. Zakona (st. 3.). Ako privatna isprava po svom obliku i sadržaju ne odgovara zahtjevima iz stavka 3. ovoga članka, potvrda će se izvršiti stavljanjem posebnog javnobilježničkog akta. Privatna se isprava u tom slučaju mora prošiti s javnobilježničkim aktom, i smatrat će se sastavnim dijelom i dopunom javnobilježničkog akta. U tom slučaju privatnu ispravu potpisuje i javni bilježnik i svjedoci (st. 4.). 
tako, nema nikakve zapreke da se ugovor o zakupu solemnizira i u slučaju ako zakupodavac nije osoba javnoga prava, čak štoviše čini nam se da bi to bilo korisno, neovisno o troškovima koji nastaju kod javnog bilježnika. U svezi s tim se u praksi navodi „da kada se radi o obavezi plaćanja zakupnine u ugovorenom mjesečnom iznosu, potvrdu o ovršnosti po prirodi stvari javni bilježnik ne može dati već u vrijeme nastanka takve isprave nego tek onda kad utvrdi je li i u kojem dijelu, odnosno za koji iznos tražbina iz ovršne isprave dospjela“" ${ }^{58}$

Daljnja specifičnost kod zasnivanja zakupa odnosi se na zakupu poslovnog prostora u vlasništvu Republike Hrvatske i jedinica lokalne i područne (regionalne) samouprave te pravnih osoba u njihovu vlasništvu ili pretežitom vlasništvu. U tom slučaju obvezatan je javni natječaj ${ }^{59}$, s time da su predviđeni i određeni izuzetci od tog pravila. No u praksi se navodi ,da na davanje u zakup poslovnog prostora ne dolazi do primjene odredbe Zakona o zaštiti tržišnog natjecanja“. ${ }^{60}$

Tako javni natječaj nije potreban ako ugovor o zakupu poslovnog prostora sklapaju međusobno Republika Hrvatska i jedinice lokalne i područne (regionalne) samouprave te pravne osobe u vlasništvu ili pretežitom vlasništvu Republike Hrvatske odnosno pravne osobe u vlasništvu ili pretežitom vlasništvu jedinice lokalne i područne (regionalne) samouprave, pod uvjetom da je to u interesu i cilju općega, gospodarskog i socijalnog napretka njezinih građana. Druga iznimka od potrebe provođenja javnog natječaja za davanje u zakupu poslovnog prostora postoji kada sadašnji zakupnik u potpunosti izvršava svoje obveze iz ugovora o zakupu. U tom slučaju zakupodavac je dužan takvom zakupniku najkasnije 60 dana prije isteka roka na koji je ugovor sklopljen ponuditi sklapanje novog ugovora o zakupu na određeno vrijeme, ali ne dulje od 5 godina. Pod sadašnjim zakupnikom podrazumijeva se zakupnik koji sada koristi poslovni prostor na temelju valjanoga ugovora o zakupu. Zakupnik ima pravo podnijeti zakupodavcu zahtjev za davanje ponude najkasnije 90 dana prije isteka roka na koji je ugovor sklopljen. Ako sadašnji zakupnik ne bi prihvatio ponudu u roku od 30 dana, tada bi zakupni odnos prestao istekom roka na koji je ugovor sklopljen. U tom slučaju zakupodavac je dužan za taj poslovni prostor raspisati javni natječaj za davanje u zakupu tog poslovnog prostora u kojem početni iznos zakupnine ne može biti manji od iznosa zakupnine koji je bio ponuđen sadašnjem zakupniku, pod uvjetom da će se u prostoru nastaviti obavljati ista djelatnost. Postupak natječaja provodi i odluku o najpovoljnijoj ponudi donosi Državni ured za upravljanje državnom imovinom, župan, gradonačelnik Grada Zagreba, gradonačelnik ili općinski načelnik, odnosno od njih ovlašteno tijelo, a za pravne osobe u njihovu vlasništvu ili pretežitom vlasništvu nadležno tijelo utvrđeno aktima te pravne osobe. Najpovoljnijom ponudom smatrat će se ona ponuda koja uz ispunjenje uvjeta iz natječaja sadrži i najviše iznos zakupnine. Prvenstveno pravo na sklapanje ugovora o zakupu imaju osobe iz Zakona o pravima hrvatskih branitelja iz Domovinskog rata i članova njihovih obitelji ukoliko ispunjavaju uvjete iz natječaja

58 ŽS Dubrovnik, Gž-660/05 od 10.VI.2005. - www.ingbiro.com.

59 Čl. 6. ZZKPP.

60 US RH, Us-6699/01 od 3.XI.2005. - www.ingbiro.com. 
i ako prihvate najviši ponuđeni iznos zakupnine. U praksi se tako navodi „da je dopušteno zahtijevati utvrđenje ništavosti ugovora o zakupu poslovnog prostora, ali ne i postupka provedbe javnog natječaja za davanje poslovnog prostora u zakup“ “. ${ }^{61}$ No, isto tako ,tužbom se ne može zahtijevati utvrđenje da je tužitelj najpovoljniji ponuditelj na natječaju objavljenom radi davanja u zakup poslovnog prostora". ${ }^{62}$

S obzirom na opće poznato stanje zemljišnih knjiga, kao i činjenicu da Republika Hrvatska, ali i jedinice lokalne i područne (regionalne) samouprave još uvijek nisu upisale vlasništvo u svoju korist na velikom broju nekretnina, dobro je da se zakonodavac odlučio da propiše da se gore navedena pravila odnose i na poslovni prostor koji je još uvijek upisan u zemljišnim knjigama kao društveno vlasništvo na kojem Republika Hrvatska i jedinice lokalne i područne (regionalne) samouprave i druge pravne osobe imaju pravo raspolaganja ili korištenja. Kada to ne bi bio slučaj, te kada bi se tražilo da se za davanje u zakup poslovnog prostora uvijek mora imati sređeno zemljišnoknjižno stanje, tada jedan dio poslovnih prostora, zbog nesređenog zemljišnoknjižnog stanja, ne bi uopće mogao biti dan u zakup.

Ugovorne strane ugovora o zakupu su zakupodavac i zakupnik te svaka ugovorna strana ima određena prava i obveze.

Obveza je zakupodavca da preda zakupniku poslovni prostor u roku utvrđenom ugovorom, s time da ukoliko zakupodavac ne bi zakupniku predao poslovni prostor u ugovorenom roku, tada zakupnik svoje pravo može ostvariti tužbu, dakle tražiti predaju u posjed poslovnog prostora, odnosno raskinuti ugovor, a isto tako zakupnik ima pravo na naknadu štete ${ }^{63}$ Kod toga ,okolnost da se u poslovnom prostoru nalazi treća osoba - raniji zakupnik (koji se poziva na svoje pravo zadržanja), zakupodavca ne oslobađa ugovorne obveze predaje poslovnog prostora sadašnjem zakupniku“ ${ }^{64}$ Vezano uz rok predaje u praksi se nalazi i shvaćanje „da kad ugovorom o zakupu u vezi s obvezom zakupodavca na predaju u posjed poslovnog prostora nije ugovoren poseban uvjet ili rok, da tada treba smatrati da se zakupodavac obvezao predati ga u posjed zakupniku odmah". ${ }^{65}$

Daljnja obveza zakupodavca je da zakupniku preda poslovni prostor u stanju utvrđenom ugovorom, no ako ugovorom nije utvrđeno u kakvom stanju zakupodavac predaje zakupniku poslovni prostor tada se smatra da je poslovni prostor predan u stanju prikladnom za obavljanje djelatnosti predviđene ugovorom. Izuzetno bitnim nam se čini da se pri samom činu primopredaje poslovnog prostora zakupodavca zakupniku sastavi zapisnik u koji se unose podatci o stanju poslovnog prostora $^{66}$. Upravo predmetni zapisnik često puta je vrlo koristan dokaz u sudskom sporu radi otkaza ugovora o zakupu, odnosno raskida ugovora o zakupu.

61 VSRH, Rev 312/07-2 od 29.IV.2009. - www.ingbiro.com.

62 VSRH, Rev-317/05-2 od 26.IV.2005. - www.ingbiro.com.

63 C̆l. 7. ZZKPP.

64 VSRH, Gzz 18/06-2 od 12.X.2006. - www.ingbiro.com.

65 VSRH, Gzz 18/06-2 od 12.X.2006. - www.ingbiro.com.

66 Čl. 8. i 9. ZZKPP. 
Ukoliko zakupodavac ne bi zakupniku predao poslovni prostor u stanju utvrđenom ugovorom, tada je pravo zakupnika da raskine ugovor o zakupu, ili da traži razmjerno sniženje zakupnine, ili da na teret zakupodavca sam dovede poslovni prostor u takvo stanju, pod uvjetom da to nije učinio zakupodavac nakon što ga je zakupnik na to pozvao i ostavio mu za to primjeren rok. Primjerenim rokom smatra se rok u kojem se određeni radovi mogu izvesti uzimajući u obzir pripreme, mjesto i prilike pod kojima se radovi moraju izvesti. I u ovom slučaju zakupnik ima pravo na naknadu štete ${ }^{67}$.

Pravo je zakupnika da, ako za to postoji potreba, traži od zakupodavca da izvrši popravke na poslovnom prostoru koji padaju na teret zakupodavca. Zakupnik $\mathrm{u}$ tom slučaju mora pisano obavijestiti zakupodavca i odrediti mu primjereni rok za te popravke. Ukoliko zakupodavac ne bi u roku izvršio popravke koje je dužan, zakupnik ima pravo sam izvršiti popravke na teret zakupodavca ili raskinuti ugovor. Za zakupnika je izuzetno bitno da pisano obavijesti zakupodavca o potrebi popravaka i da mu za to odredi primjereni rok, jer ako to ne bi učinio, tada zakupnik, ako bi sam izvršio popravak, ne bi imao pravo tražiti naknadu za izvršene radove, a uz to bi odgovarao za štetu zakupodavcu koju bi on zbog toga trpio, osim u slučaju hitnih popravaka. ${ }^{68}$

Za vrijeme trajanja popravka radi održavanja poslovnog prostora u stanju u kojem ga je zakupodavac dužan održavati i koji padaju na teret zakupodavca, kao i radova na javnim površinama, pročelju i krovištu zgrade, a zbog kojih zakupnik nije mogao koristiti poslovni prostor, zakupnik nije dužan plaćati zakupninu. No, zakupnik ne bi u tom slučaju imao pravo na izmaklu dobit, a ako bi poslovni prostor mogao samo djelomično koristiti ili postoji djelomična ograničenost u obavljanju poslovne djelatnosti, tada je zakupnik dužan plaćati razmjerni dio zakupnine. Ova pravila ne vrijede u slučaju ako se radi o slučajevima neznatnog ometanja, primjerice ako je zakupnik spriječen u korištenju poslovnog prostora nekoliko sati ili nekoliko dana po sat, dva i slično, ako je primjerice stavljena građevinska skela radi nekog popravka, a radi te skele je zaklonjen ulaz u poslovni prostor ili izlog poslovnog prostora i slično. ${ }^{69}$

Zakupodavac ima pravo za vrijeme trajanja zakupa izvršiti radove radi uređenja prostora ili snižavanja troškova energije i održavanja. U tom je slučaju zakupodavac dužan najkasnije dva mjeseca prije početka radova pisano obavijestiti zakupnika o vrsti, početku i opsegu radova, roku trajanja radova, kao i novoj visini zakupnine. Pravo je zakupnika u tom slučaju, da u roku od mjesec dana od dana primitka obavijesti, raskine ugovor i u istom roku o tome obavijesti zakupodavca, kojem je u daljnjem roku od 15 dana od poslane obavijesti dužan prostor predati u posjed. U slučaju bilo kakve zlouporabe prava zakupodavac odgovara zakupniku za pretrpljenu štetu ${ }^{70}$. Zakupnik nije dužan raskinuti ugovor o zakupu zbog radova.

67 Čl. 10. ZZKPP.

68 Čl. 11. ZZKPP.

69 Čl. 12. ZZKPP.

70 Čl. 13. ZZKPP. 
U tom slučaju ima pravo plaćati razmjerni dio zakupnine, ili uopće ne plaćati zakupninu, ali nema pravo na naknadu štete zbog izmakle dobiti. Pravo na izmaklu dobit zakupnik bi mogao ostvariti tek ako zakupodavac ne bi završio radove u roku navedenom u obavijesti, osim ako radovi nisu završeni zbog okolnosti za koje zakupodavac ne odgovara. ${ }^{71}$ „Za suđenje u odštetnoj parnici zbog uporabe poslovnog prostora nakon isteka ugovora o zakupu sklopljenog između dvaju trgovačkih društava nadležan je općinski sud“. ${ }^{72}$

U sudskoj praksi relativno su česti sporovi zbog izvršenih preinaka poslovnog prostora od strane zakupnika odnosno ulaganja koja je zakupnik vršio u poslovni prostor. Zakupnik ne smije bez izričite pisane suglasnosti zakupodavca činiti preinake poslovnog prostora kojima se mijenja konstrukcija, raspored, površina, namjena ili vanjski izgled poslovnoga prostora. Ako bi zakupnik to radio unatoč protivljenju zakupodavca, tada bi zakupodavac imao pravo raskinuti ugovor, a u svakom slučaju ima pravo na naknadu štete ${ }^{73}$. No isto tako ,kad su ugovorom o zakupu ugovorena ulaganja zakupnika kao i način vraćanja tih ulaganja za cijelo vrijeme trajanja zakupa kroz smanjenje zakupnine, radi se o ugovornom odnosu, na koji se ne primjenjuju pravila o stjecanju bez osnove“" ${ }^{74}$

Osnovna je obveza zakupnika da plati ugovorom utvrđeni iznos zakupnine u roku utvrđenom ugovorom. Ukoliko je zakupodavac Republika Hrvatska, odnosno jedinica lokalne i područne (regionalne) samouprave zakupnik je dužan plaćati zakupninu mjesečno unaprijed i to najkasnije do desetog dana u mjesecu. Zakupnina se prema tome slobodno može ugovarati. U slučaju kada je zakupodavac Republika Hrvatska, odnosno jedinica lokalne i područne (regionalne) samouprave zakupnina je onaj iznos koji je postignut na javnom natječaju, kao najpovoljnija ponuda. Zakupnina bi se trebala plaćati mjesečno unaprijed $\mathrm{i}$ to najkasnije do desetog $\mathrm{u}$ mjesecu. ${ }^{75}$

Zakupnik je dužan plaćati naknadu za troškove korištenja zajedničkih uređaja i obavljanja zajedničkih usluga u zgradi u kojoj se nalazi poslovni prostor po njihovom dospijeću, pri čemu se smatra da naknada za te troškove nije uračunata $u$ zakupninu, ukoliko to ugovorom nije izričito ugovoreno. ${ }^{76}$

U sudskoj praksi je tako zauzeto shvaćanje da ,nije ništava odredba ugovora o zakupu poslovnog prostora kojom se zakupac obvezao plaćati, pored zakupnine, iznos poreza koji inače tereti zakupodavca." ${ }^{\text {"77 }}$

Troškove tekućeg održavanja, a pod čime se misli na troškove čišćenja, soboslikarskih radova, sitnijih popravaka na instalacijama, snosi zakupnik, ako nije drukčije ugovoreno. Isto tako zakupnik je sam dužan o svom trošku izvršiti

$\overline{71 \text { Čl. 14. ZZKPP. }}$

72 ŽS Dubrovnik Gž-2299/07 od 13.III.2008. - www.ingbiro.com.

73 Čl. 15. ZZKPP.

74 VSRH, Rev 516/07-2 od 12.IX.2007. - www.ingbiro.com.

75 Čl. 16. ZZKPP.

76 Čl. 17. ZZKPP.

77 VSRH, Rev-2886/99 od 14. siječnja 2003., Izbor odluka 1/2003, sentenca 38. 
popravke oštećenja poslovnog prostora koja je sam prouzročio ili su ih prouzročile osobe koje se koriste poslovnim prostorom zakupnika. Zakupnik ne odgovara za pogoršanje stanja poslovnog prostora, uređaja i opreme koje je nastalo zbog redovitog korištenja. ${ }^{78}$

Jednako kao što zakupnik nema pravo vršiti preinake u poslovnom prostoru bez izričite suglasnosti zakupodavca, također nije ovlašten poslovni prostor ili dio prostora dati u podzakup, pri čemu se na ugovor o podzakupu na odgovarajući način primjenjuju odredbe zakona koje se odnose na zakup poslovnoga prostora. Bitno je naglasiti da osobe koje su sklopile ugovor o zakupu poslovnog prostora na temelju prvenstvenog prava na temelju Zakona o pravima hrvatskih branitelja iz Domovinskog rata $\mathrm{i}$ članova njihove obitelji, ne mogu dati poslovni prostor $\mathrm{u}$ $\operatorname{podzakup}^{79}$.

Daljnja je obveza zakupnika da nakon prestanka ugovora o zakupu preda zakupodavcu poslovni prostor u stanju u kojem ga je primio, ako nije drukčije ugovoreno ili propisano. Čini nam se korisnim da i u tom slučaju ugovorene strane sačine zapisnik kojim bi se konstatiralo stanje u kojem se poslovni prostor vraća zakupodavcu. U ovom slučaju zakupnik ima pravo odnijeti uređaje koje je ugradio u poslovni prostor, ako ne oštećuje poslovni prostor i ako mu to ulaganje zakupodavac nije priznao kroz smanjenje visine zakupnine. ${ }^{80}$

Kada se govori o prestanku ugovora o zakupu, tada se razlikuju ugovor o zakupu na neodređeno vrijeme i ugovor o zakupu na određeno vrijeme. Ugovor o zakupu poslovnog prostora sklopljen na određeno vrijeme prestaje istekom vremena na koji je sklopljen ${ }^{81}$. To znači da nakon isteka ugovorenog vremena zakupa, zakupni odnos prestaje, pa ako bi nakon tog vremena zakupnik i nadalje ostao u posjedu prostora, tada bi isti poslovni prostor koristio bez valjane osnove.

S druge strane ugovor o zakupu poslovnog prostora sklopljen na neodređeno vrijeme prestaje otkazom. Taj ugovor ne može na temelju otkaza prestati prije isteka jedne godine od dana sklapanja, ako ugovorom nije drukčije određeno. ${ }^{82}$ ZZKPP daje mogućnost da ugovorne strane ugovore pojedine odredbe drukčije nego što je to propisano. ${ }^{83}$ Tako se u sudskoj praksi navodi ,da ako su stranke sklopile ugovor o zakup za određeno vrijeme, u kojem su ugovorile da bilo koja ugovorna stranka ima pravo raskinuti taj ugovor u vremenu trajanja ugovora, uz otkazni rok od 30 dana, onda je moguć jednostrani raskid takvog ugovora u svako dobra, budući da Zakon o zakupu poslovnog prostora ne propisuje takvu mogućnosti, ali je niti ne zabranjuje, iz kojeg razloga se u konkretnom slučaju primjenjuje načelo dispozitivnosti propisano odredbom čl. 10. ZOO“. ${ }^{84}$

78 Čl. 18. ZZKPP.

79 Čl. 19. ZZKPP.

80 Čl. 20. i 21. ZZKPP.

81 Čl. 22. ZZKPP.

82 Čl. 23. ZZKPP.

83 „Ugovor o zakupu poslovnog prostora ne može se raskinuti prostom izjavom.“ (Vrhovni sud Republike Hrvatske, Rev-1485/96 od 18. travnja 2000., Izbor odluka 2/2000, sentenca 29).

84 ŽS Varaždin, Gž-1341/05-2 od 3.XI.2005. - www.ingbiro.com. 
Dok ugovor o zakupu poslovnog prostora sklopljen na određeno vrijeme prestaje istekom vremena na koje je sklopljen, ugovor o zakupu poslovnog prostora sklopljen na neodređeno vrijeme prestaje danom isteka otkaznog roka. ${ }^{85}$ Otkazni je rok vrijeme između dana dostave otkaza protivnoj stranci i dana kad prestaje zakupu . Otkazni rok je 30 dana, s time da ugovorne strane imaju mogućnost ugovoriti i drugi vremenski period, a ako nije drukčije ugovoreno, otkaz se može dati samo prvoga ili petnaestoga dana u mjesecu. ${ }^{86}$

Ugovor o zakupu poslovnog prostora sklopljen na neodređeno vrijeme otkazuje se pisanim otkazom koji se dostavlja poštom preporučeno, a putem javnog bilježnika kada je ugovor potvrđen (solemniziran) po javnom bilježniku. Kada se otkaz daje putem javnog bilježnika, tada javni bilježnik sastavlja zapisnik o tome i poduzima sve radnje propisane zakonom te taj zapisnik ima snagu ovršne isprave. Ovrha se u tom slučaju može tražiti na temelju ugovora o zakupu i zapisnika koji je sastavio javni bilježnik. ${ }^{87}$

Zakupodavac ima pravo otkazati ugovor o zakupu u svako doba, bez obzira na ugovorne ili zakonske odredbe o trajanju zakupa u tri slučaja:

1. ako zakupnik i poslije pisane opomene zakupodavca koristi poslovni prostor protivno ugovoru ili mu nanosi znatniju štetu koristeći ga bez dužne pažnje,

2. ako zakupnik ne plati dospjelu zakupninu, u roku od 15 dana do dana priopćenja pisane opomene zakupodavca,

3. ako zakupodavac, zbog razloga za koje on nije odgovoran, ne može koristiti poslovni prostor u kojem je obavljao svoju djelatnost pa zbog toga namjerava koristiti prostor koji drži zakupnik. ${ }^{88}$

S druge strane zakupnik može otkazati ugovor o zakupu u svako doba, bez obzira na ugovorne ili zakonske odredbe o trajanju zakupa, ako zakupodavac u primjerenom roku koji mu je zakupnik za to ostavio ne dovede poslovni prostor u stanje u kojemu ga je dužan predati, odnosno održavati. I zakupodavac i zakupnik mogu u svako doba otkazati ugovor o zakupu (sklopljen na određeno ili neodređeno vrijeme) ako druga ugovorna strana ne izvršava svoje obveze utvrđene ugovorom ili Zakonom. ${ }^{89}$

U sudskoj praksi je tako izraženo shvaćanje da je „otkaz ugovora o zakupu poslovnog prostora zbog neplaćanja zakupnine pravno valjan i proizvodi učinke i onda kad prethodna pismena opomena o neplaćanju zakupnine nije bila uručena zakupcu, kad dužnu dospjelu zakupninu zakupac ne plati ni nakon uručenja pismenog otkaza, a ni nakon primitka tužbe za iseljenje podnesene po proteku

85 Nakon stupanja na snagu Zakona o zakupu poslovnih prostorija (Narodne novine, br. 91/96) sud više nije nadležan za provođenja postupka za otkaz ugovora o zakupu poslovnih prostorija, pa takav otkazni nalog valja odbaciti na temelju odredbe čl. 16. st. 3. ZPP. (ŽS Koprivnica, Gž-322/98 od 17. svibnja 1998., Izbor odluka 1/1998, sentenca 182).

86 Čl. 24. ZZKPP.

87 Čl. 25. ZZKPP.

88 Čl. 26. ZZKPP.

89 Čl. 27. i 28. ZZKPP. 
otkaznog roka“.90 Isto tako ,tražbina zakupoprimca s naslova izvršenih ulaganja u poslovni prostor zastarijeva u općem zastarnom roku od 5 godina, a počinje teći iseljenjem zakupoprimca“. ${ }^{91}$ Oko istog pitanja je rečeno da ,potraživanje zakupnika s naslova ulaganja koje je izvršio u poslovni prostor zastarijeva u roku od pet godina, a rok počinje teći pravog dana nakon što je zakupnik prestao koristiti poslovni prostor“.$^{92}$ „Kad je zakupac poslovnog prostora i nakon povrata prostora ranijem vlasniku po Zakonu o naknadi nastavio plaćati zakupninu ranijem zakupodavcu, nije riječ o stjecanju bez osnove na štetu vlasnika jer njegova imovina nije prešla u imovinu ranijeg zakupodavca niti je on upotrebljavao vlasnikovu stvar. Vlasnik i raniji zakupodavac nisu ni u kakvom pravnom odnosu kad je u pitanju zakup. “93 Nadalje „kada tužitelj traži naknadu za korištenje poslovnog prostora kojeg tuženik nakon isteka ugovora o zakupu bespravno koristi, ne radi se o zakupnini, već o naknadi koristi koju tuženi ima od uporabe tuđe stvari pa nema primjene odredaba o zastari samog prava i to potraživanje zastarijeva u općeg zastarnom roku od pet godina“. ${ }^{94}$ Sudska praksa govori o pravu na razmjerni dio zakupnine, pa se tako navodi da ,suvlasnica poslovnog prostora, koji u cijelosti bez pravne osnove koristi tuženik, ima pravo potraživati od tuženika razmjerni dio zakupnine koji odgovara njenom suvlasničkom omjeru, iako nije osporila vršenje obrtničke djelatnosti tuženika u poslovnom prostoru“. ${ }^{95}$ Glede izvršenih ulaganja nalazimo i odluku prema kojoj ,iako se zakupnik obvezao urediti poslovni prostor o svom trošku, povodom sporazumnog raskida ugovora (nakon 10 mjeseci) prije ugovorenog roka (od 10 godina) zakupodavac mu duguje naknadu za korist koju je stekao tim ulaganjima“.96 Također ,zakupniku ne pripada pravo uskratiti plaćanje zakupnine zbog nedostataka i neizvršavanja popravaka poslovnog prostora osim ako je zakupnik sam izvršio popravke i s tim u svezi imao troškove“ ${ }^{97}$

I pri vraćanju poslovnog prostora zakupnika zakupodavcu, dakle kod prestanka ugovora o zakupu, predviđeno je da se sastavi zapisnik o stanju u kojem se prostor nalazi, no ako se pri vraćanju zapisnik ne bi sačinio, tada se smatra da je poslovni prostor predan $\mathrm{u}$ ispravnom stanju ${ }^{98}$.

Do prestanka zakupa ne dolazi kada poslovni prostor kupnjom ili po nekoj drugoj osnovi stekne treća osoba, u kom slučaju treća osoba stupa u prava i obveze zakupodavca. Isto tako do prestanka zakupa ne dolazi niti u slučaju ako umre zakupnik, ili se pak promijeni pravni položaj zakupnika, u kom slučaju nasljednici, odnosno pravni sljednici stupaju u prava i obveze zakupnika ${ }^{99}$.

90 ŽS Bjelovar, Gž-1130/11-2 od 9.VI.2011. - www.ingbiro.com.

91 VSRH, Rev x-146/09-2 od 26.V.2009. - www.ingbiro.com.

92 VSRH, Rev 559/07-2 od 12.XII.2007. -www.ingbiro.com.

93 ŽS Dubrovnik, Gž-957/07 od 18. III.2010. - www.ingbiro.com.

94 ŽS Dubrovnik, Gž-567/08 od 21.VIII.2008. - www.ingbiro.com.

95 ŽS Varaždin, Gž-91/07 od 30.IV.2007. - www.ingbiro.com.

96 VSRH, Rev 1000/06-2 od 11.VII.2007. - www.ingbiro.com.

97 VSRH, Rev 102/05-2 od 1.III.2005. - www.ingbiro.com.

98 Čl. 29. ZZKPP.

99 Čl. 30. i 31. ZZKPP. 
Za rješavanje sporova između zakupodavca i zakupnika propisana je sudska nadležnost, a ti su postupci hitne naravi ${ }^{100}$.

Glede sudske nadležnosti u sporovima iz zakupnih odnosa zauzeto je shvaćanje „da je za suđenje u sporu iz zakupnog odnosno najamnog odnosa koji proizlazi iz trgovačkih ugovora i vodi se između osoba koje obavljaju gospodarsku djelatnost, a nad jednom od stranaka je otvoren stečajni postupak, nadležan je trgovački sud ${ }^{101 ،}$. Nadalje „za suđenje u sporu iz trgovačkog ugovora o najmu motornih vozila između osoba koje obavljaju trgovačku djelatnost stvarno je nadležan trgovački sud ${ }^{102 *}$.

Također u praksi nalazimo „da kad zakupnik po isteku ugovora o zakupu nije vratio poslovni prostor zakupodavcu, već ga je dao u podzakup, da tada mora platiti naknadu za njezino korištenje“. ${ }^{103}$

„Ustupanjem ugovora o zakupu poslovnog prostora od strane zakupnika trećoj osobi, koje je odobrio zakupodavac, na treću osobu prešla su sva prava i obveze zakupnika“. 104

\subsection{Zakup poljoprivrednog zemljišta}

Sada važeći ZPZ također propisuje u čl. 2. st. 1. da je poljoprivredno zemljište dobro od interesa za Republiku Hrvatsku i ima njezinu osobitu zaštitu. Isto tako nositelji prava vlasništva na poljoprivrednom zemljištu ne mogu biti strane pravne i fizičke osobe, osim ako međunarodnim ugovorom i posebnim propisima nije što drugo određeno. No, st. 3. istog članka propisano je da strane fizičke i pravne osobe mogu stjecati pravo vlasništva na poljoprivrednom zemljištu nasljeđivanjem. ${ }^{105}$

U čl. 7. st. 1. ZPZ-a propisana je obveza fizičke ili pravne osobe da prati stanje poljoprivrednog zemljišta u vlasništvu države koje koriste na temelju ugovora o zakupu, zakupu zajedničkog pašnjaka i zakupu za ribnjake.

Čl. 14. st. 1. ZPZ-a propisano je da se neizgrađeno građevinsko zemljište u vlasništvu države koje je po uporabnom svojstvu poljoprivredno zemljište daje u zakup fizičkoj ili pravnoj osobi za poljoprivredne namjene. To zemljište Agencija za poljoprivredno zemljište (dalje Agencija) daje u zakup uz suglasnost Državnog ureda za upravljanje državnom imovinom, putem javnog poziva na rok od 10 godina, s ugovornom klauzulom o raskidu ugovora nakon završetka vegetativne sezone, odnosno nakon dobivanja akta kojim se odobrava građenje, potvrde glavnog projekta ili rješenja o izvedenom stanju, do privođenja tog zemljišta namjeni utvrđenoj prostornim planom, odnosno do pravomoćnosti rješenja o povratu

100 Čl. 32. ZZKPP.

101 VSRH, Gr1 333/05-2 od 23.V.2005. - www.ingbiro.com.

102 VSRH, Gr1 672/04-2 od 20.V.2005. -www.ingbiro.com.

103 ŽS Zagreb, Gž-3754/04 od 29.XI.2005. - www.ingbiro.com.

104 VSRH, Rev-1346/01 od 5.II.2002. - www.ingbiro.com.

105 Vidi opširnije Damir Kontrec, Pravni status i raspolaganje poljoprivrednim zemljištem u Republici Hrvatskoj, povijesni prikaz, de lege lata, de lege ferenda, Radovi 25, HAZU, Zavod za znanstveni rad Varaždin, 2015. str. 69-95. 
sukladno posebnom propisu. I na davanje u zakup neizgrađenog građevinskog zemljišta koje je po uporabnom svojstvu poljoprivredno zemljište na odgovarajući se način primjenjuju odredbe čl. 27. do 45. ZPZ-a.

Poljoprivrednim zemljištem u vlasništvu Republike Hrvatske može se raspolagati:

- zakupom,

- zakupom za ribnjake,

- zakupom zajedničkih pašnjaka,

- privremenim raspolaganjem,

- zamjenom,

- prodajom izravnom pogodbom,

- davanjem na korištenje bez javnog poziva,

- razvrgnućem suvlasničke zajednice,

- osnivanjem prava građenja,

- odnosno osnivanjem prava služnosti. ${ }^{106}$

Prema odredbi čl. 27. st. 1. ZPZ-a poljoprivredno zemljište u vlasništvu države daje se u zakup i zakup za ribnjake putem javnog poziva na rok od 50 godina. Odluku o raspisivanju javnog poziva za dodjelu zakupa i zakupa za ribnjake donosi Agencija. Poziv za zakup raspisuje se ponajprije za katastarske čestice koje čine proizvodno-tehnološke cjeline, površine najviše do 100 hektara. Ako Agencija utvrdi da se poljoprivredno zemljište nalazi unutar područja ekološke mreže, poziv na zakup i zakup za ribnjake sadrži i posebne uvjete zaštite prirode koje na zahtjev Agencije utvrđuje središnje tijelo državne uprave nadležno za poslove zaštite prirode. Samo iznimno se može raspisati poziv za zakup i za površine veće od 100 hektara, ako tu proizvodno-tehnološku cjelinu čini jedna katastarska čestica. Isto tako iznimno se može u javnom pozivu odrediti vrsta poljoprivredne proizvodnje za koju se poljoprivredno zemljište u vlasništvu države daje u zakup, s obzirom na specifične agroklimatske potencijale pojedine regije. Iznimno se također može poziv za zakup raspisati za katastarsku česticu na kojoj je izgrađena građevina u vlasništvu države, odnosno za tu česticu i susjedne katastarske čestice koje s njom čine proizvodno-tehničku cjelinu.

Samu odluka o dodjeli zakupa i zakupa za ribnjake donosi Agencija na prijedlog Povjerenstva za dodjelu zakupa na poljoprivrednom zemljištu u vlasništvu Republike Hrvatske, odnosno Povjerenstva za dodjelu zakupa na poljoprivrednom zemljištu u vlasništvu Republike Hrvatske za ribnjake.

Jedinice lokalne samouprave dostavljaju Agenciji zahtjev za raspisivanje javnog poziva i dokumentaciju potrebnu za raspisivanje javnog poziva za zakup i zakup za ribnjake. Dokumentacija i zahtjevi podnose se prvenstveno za proizvodnotehnološke cjeline poljoprivrednog zemljišta ili ribnjaka. Zahtjev za prikupljanje dokumentacije za raspisivanje javnog poziva za zakup i zakup za ribnjake jedinici lokalne samouprave može podnijeti zainteresirana fizička ili pravna osoba. No, isto

106 Čl. 25. st. 2. ZPZ. 
tako i Agencija može sama donijeti odluku o raspisivanju javnog poziva za zakup i zakup za ribnjake, ako je sama pribavila potrebnu dokumentaciju za raspolaganje poljoprivrednim zemljištem u vlasništvu države, pri čemu je sama dokumentacija propisana podzakonskim aktima. ${ }^{107}$

Na javni poziv za zakup i zakup za ribnjake mogu se javiti nositelji obiteljskog poljoprivrednog gospodarstva, zadruge koje se bave poljoprivrednom djelatnošću, odnosno djelatnošću akvakulture ili čiji su zadrugari poljoprivredni proizvođači i druge fizičke ili pravne osobe, a koje su do isteka roka za podnošenje ponuda platile sve obveze s osnova korištenja poljoprivrednog zemljišta u vlasništvu države, odnosno sve druge obveze s osnova koncesije, naknadu za vodu za ribnjake, naknadu za korištenje vode za navodnjavanje, te protiv kojih se ne vodi postupak radi predaje u posjed poljoprivrednog zemljišta. Izrijekom je propisano da se na javni poziv ne mogu javiti osobe kojima je ranije bilo dodijeljeno poljoprivredno zemljište u vlasništvu države, a koje su to zemljište dale u podzakup, odnosno koje su tim zemljištem neovlašteno raspolagale. Isto tako nevažeća je i zajednička ponuda ponuditelja na pozivu za zakup i zakup za ribnjake. Ako je sudionik javnog poziva za zakup i zakup za ribnjake zadruga koja se bavi poljoprivrednom djelatnošću, tada je nevažeća ponuda sudionika koji je član te zadruge. Također je ponuda nevažeća ako ponuđena zakupnina na pozivu za zakup i za zakup za ribnjake ponuditelja koji ispunjava pozive uvjete prelazi dvostruki iznos početne zakupnine.

Ponuda za zakup i ponuda za zakup za ribnjake moraju se podnijeti odvojeno. Sastavni dio ponude obrazac je Gospodarskog programa korištenja poljoprivrednog zemljišta u vlasništvu države.

Prema čl. 30. ZPZ-a pravo prvenstva na pozivu za zakup imaju nositelji obiteljskog poljoprivrednog gospodarstva, zadruge koje se bave poljoprivrednom djelatnošću ili čiji su zadrugari poljoprivredni proizvođači i druge fizičke ili pravne osobe koje su sudjelovale u pozivu i ostvarile najviši zbroj bodova od ukupno mogućih 100 bodova. Pritom je samo bodovanje propisano na način:

107 Tako su doneseni posebni podzakonski akti:

- Pravilnik o početnoj zakupnini poljoprivrednog zemljišta u vlasništvu Republike Hrvatske za zakup i zakup za ribnjake, Narodne novine, br. 107/13;

- Pravilnik o dokumentaciji potrebnoj za raspisivanje javnog poziva za zakup, zakup za ribnjake i zamjenu poljoprivrednog zemljišta u vlasništvu Republike Hrvatske, Narodne novine, br. 84/13, 45/14;

- Pravilnik o postupku javnog nadmetanja za utvrđivanje najpovoljnijeg ponuditelja na javnom pozivu za dodjelu poljoprivrednog zemljišta u vlasništvu Republike Hrvatske u zakup i zakup za ribnjake, Narodne novine, br. 120/13, 98/15;

- Pravilnik o načinu vođenja evidencije o promjeni namjene poljoprivrednog zemljišta, Narodne novine br. 149/13;

- Pravilnik o načinu vođenja registra zajedničkih pašnjaka u vlasništvu Republike Hrvatske, Narodne novine, br. 18/14;

- Pravilnik o načinu i uvjetima za podnošenje zahtjeva za raspisivanje javnog poziva te kriterijima za dodjelu u zakup zajedničkih pašnjaka u vlasništvu Republike Hrvatske, Narodne novine, br. 68/15. 
- da se Gospodarski program ocjenjuje s najviše 60 bodova,

- činjenica da je dosadašnji posjednik bio u mirnom posjedu na temelju valjano provedenog natječaja najviše 20 bodova,

- činjenica da je dosadašnji posjednik bio u mirnom posjedu najviše 10 bodova,

- te činjenica ako je nositelj obiteljskoga poljoprivrednog gospodarstva koji je mlađi od 40 godina, upisan u Upisnik poljoprivrednih gospodarstava više od jedne godine i nema u zakupu poljoprivredno zemljište u vlasništvu države najivše 10 bodova,

- visina ponuđene zakupnine do najviše 10 bodova,

- prebivalište, sjedište najmanje dvije godine na području jedinice lokalne samouprave odnosno Grada Zagreba, najviše 10 bodova.

Pravo prvenstva na pozivu za zakup za ribnjake imaju nositelji obiteljskog poljoprivrednog gospodarstva, zadruge koje se bave poljoprivednom djelatnošću, odnosno djelatnošću akvakulture ili čiji su zadrugari poljoprivredni proizvođači i druge fizičke ili pravne osobe koje su sudjelovale u pozivu i ostvarile najviše zbroj mogućih bodova od ukupno mogućih 100 bodova. U ovom slučaju bodovanje se vrši na način:

- da se Gospodarski program boduje s najviše 60 bodova,

- dosadašnji posjednik ako je u mirnom posjedu temeljem ugovora o privremenom korištenju ili ugovora o koncesiji za korištenja voda prema posebnom propisu najviše 20 bodova,

- te visina zakupnine do najviše 20 bodova.

Početnu visinu zakupnine posebnim pravilnikom propisuje ministar poljoprivrede. Ako je više osoba izjednačeno prema broju bodova, tada se najpovoljniji ponuditelj utvrđuje javnim nadmetanjem, koji postupak također propisuje pravilnikom nadležni ministar.

Na temelju odluke o izboru najpovoljnije ponude na pozivu za zakup i zakup za ribnjake ravnatelj Agencije u ime Republike Hrvatske i podnositelj ponude sklapaju ugovor o zakupu i ugovor o zakupu za ribnjake u pisanom obliku, pri čemu je pisani oblik uvjet pravne valjanosti takvog ugovora. Ponuditelj treba prije sklapanja ugovora dostaviti dokaz da je namirio sve obveze s osnove korištenja poljoprivrednog zemljišta u vlasništvu države. Gospodarski program sastavni je dio navedenih ugovora o zakupu. Zakupnik je dužan podnositi godišnje izvješće Agenciji o ispunjavanju ciljeva Gospodarskog programa. U slučaju potrebe može se kasnije sklopiti aneks ugovora o zakupu i to nakon proteka roka od pet godina od sklapanja ugovora o zakupu i zakupu za ribnjake. Vezano uz oblik ugovora u sudskoj praksi je zauzeto shvaćanje ,da pisani oblik za ugovor o zakupu nekretnine kao pretpostavku valjanosti takvog pravnog posla propisuje Zakon o poljoprivrednom zemljištu za poljoprivredno zemljište u vlasništvu države, što znači da se navedena pretpostavka valjanosti pravnog posla ne odnosi i na ugovor o zakupu nekretnine (poljoprivrednog zemljišta) u vlasništvu drugih fizičkih i pravnih osoba". ${ }^{108}$ 
Agencija je dužna primjerak ugovora o zakup i zakupu za ribnjake dostaviti nadležnom katastarskom uredu i zemljišnoknjižnom sudu i to u roku od 30 dana od dana sklapanja, sve u svrhu upisa navedenog ugovora u evidencije o nekretninama. Primjerak ugovora o zakupu i ugovora o zakupu za ribnjake dostavlja se i jedinici lokalne samouprave na čijem se području nekretnina nalazi, a ugovor o zakupu za ribnjake se dostavlja i Hrvatskim vodama. U praksi nalazimo shvaćanje prema kojem „kad je ostavitelj koristio zemljište na temelju ugovora o zakupu poljoprivrednog zemljišta sklopljenog s njim kao hrvatskim braniteljem, posjed zemljišta ne prelazi na nasljednike. S obzirom na karakter ugovora, on prestaje časom smrti zakupnika, pa je posjed koji proizlazi iz tog ugovora nenasljediv““. ${ }^{109}$

$\mathrm{Na}$ osnovi sklopljenog ugovora o zakupu i ugovora o zakupu za ribnjake zakupnika se uvodi u posjed. To čini Povjerenstvo u roku od 30 dana od dana sklapanja ugovora, odnosno skidanja usjeva ranijeg posjednika, s time da članove Povjerenstva imenuje Agencija.

Zakupnina se plaća godišnje, a za prvu godinu zakupnina se plaća u roku od 15 dana od dana uvođenja u posjed u visini razmjernoj razdoblju koje je preostalo do isteka godine, a za svaku sljedeću godinu zakupnina i naknada za vodu plaćaju se do kraja lipnja tekuće godine. U slučaju kašnjenja s plaćanjem zakupnik je dužan platiti i zateznu kamatu. Prema ranijoj sudskoj praksi „općini je pripadao do zakonu dio zakupnine iz ugovora o zakupu poljoprivrednog zemljišta koji je sklopila Republika Hrvatska kao vlasnik tog zemljišta s fizičkom osobom neovisno o tome kako su stranke nazvale taj ugovor". 110

Poljoprivredno zemljište dano u zakup ili zakup za ribnjake ne može se dati u podzakup, niti zakupnik može svoja prava iz ugovora o zakupu prenijeti na drugu osobu, pri čemu su iznimke propisane u čl. 35. st. 3. do 11. ZPZ-a.

U čl. 36. ZPP-a propisano je koje sve odredbe mora sadržavati ugovor o zakupu i ugovor o zakupu za ribnjake, pa je tako propisano da ti ugovori sadrže:

- predmet zakupa,

- vrijeme trajanja zakupa,

- visinu i rok plaćanja zakupnine,

- prava i obveze zakupnika,

- namjenu korištenja zakupljenog zemljišta,

- odustanak od ugovora,

- razloge za raskid ugovora,

- dopustivost postavljanja gospodarskih objekata, pomoćnih uređaja i objekata za iskorištavanje zemljišta,

- Gospodarski program,

- uvjete zaštite prirode ako se poljoprivredno zemljište u cijelosti ili djelomično nalazi unutar područja ekološke mreže i

- usklađivanje katastarskog i zemljišnoknjižnog stanja. 
Malo je nejasno na koji način bi ugovor o zakupu sadržavao odredbe o usklađivanju katastarskog i zemljišnoknjižnog stanja, budući da su posebnim pravilima zemljišnoknjižnog prava propisani način sređivanja nesređenog zemljišnoknjižnog stanja. Čini nam se da se ovdje primarno trebalo raditi da se u slučaju neslaganja katastarskih i zemljišnoknjižnih podataka o nekretninama u samom ugovoru o zakupu i ugovoru o zakupu za ribnjake navedu i jedne i druge oznake kako ne bi bilo dvojbe o tome što je predmet zakupa.

Sklapanjem ugovora o zakupu za ribnjake zakupnik stječe pravo korištenja kopnenih voda radi uzgoja ribe i drugih vodenih organizama pogodnih za gospodarski uzgoj za sve vrijeme trajanja zakupa.

Detaljno je propisano i kako prestaju ugovor o zakupu odnosno ugovor o zakupu za ribnjake. Tako je određeno da ti ugovori prestaju protekom vremena na koje su sklopljeni. Isto tako sporazumno ti ugovori mogu prestati u svako vrijeme.

Do raskida ugovora o zakupu i ugovora o zakupu za ribnjake dolazi ako:

- poljoprivredno zemljište prestane biti poljoprivredno zbog promjene namjene,

- ako se zemljište koristi suprotno odredbama ugovora,

- ako zakupnik ne plati zakupninu do kraja rujna tekuće godine, osim u slučaju više sile ili drugih nepredviđenih okolnosti koje nisu krivnja zakupnika,

- ako zakupnik ne koristi poljoprivredno zemljište u vlasništvu države kao dobar gospodar,

- ako zakupnik ne ostvaruje ciljeve Gospodarskog programa koji čini sastavni dio ugovora o zakupu i to dvije godine uzastopce, osim u slučaju više sile,

- ako zakupnik obrađuje poljoprivredno zemljište suprotno odredbama ugovora,

- ako daje zakupljeno zemljište u podzakup,

- ako zakupnik obavlja aktivnosti suprotno propisima o zaštiti prirode ili radnje koje imaju negativan utjecaj na bogatstvo ili stanje prirodnog područja te ako na bilo koji način ugrožava opstanak prirodnih vrijednosti,

- ako zakupnik ne iskrči poljoprivredno zemljište u vlasništvu države koje nije u funkciji poljoprivredne proizvodnje ili je obraslo višegodišnjim raslinjem u roku od dvije godine od dana uvođenja u posjed.

Zakupodavac će raskinuti ugovor o zakupu za ribnjake ako se zakupnik ne pridržava posebnih uvjeta korištenja voda, odnosno ako nakon otvaranja stečajnog postupka zakupnik kao stečajni dužni ne nastavi s korištenjem poljoprivrednog zemljišta u vlasništvu države. Glede ugovora o zakupu ribnjaka od neovlaštenog zakupodavca u praksi je zauzeto shvaćanje da „Republici Hrvatskoj pripada pravo na naknadu štete iako kao vlasnik nekretnine na temelju Zakona o poljoprivrednom zemljištu nije stupila na mjesto ranijeg zakupodavca odnosno nije poduzela radnje i tražila ispunjenja koja je prema zaključenom ugovoru o zakupu mogla tražiti““. ${ }^{111}$

111 ŽS Varaždin, Gž-358/07-2 od 4.III.2008. - www.ingbiro.com. 
Sam ugovor o zakup smatra se raskinutim danom dostave obavijesti o raskidu ugovora zakupniku. $\mathrm{U}$ obavijesti mora biti navedeno do kojeg roka zakupnik ima pravo ubrati plodove odnosno skinuti usjeve. I obavijesti o prestanku ugovora o zakupu treba dostaviti katastru i zemljišnoj knjizi, kako bi se brisao upis zakupa na toj nekretnini.

Ako su se na poljoprivrednom zemljištu u vlasništvu države na dan sklapanja ugovora o zakupu nalazili trajni nasadi, objekti i uređaji kojima se za vrijeme trajanja zakupa smanjila vrijednost krivnjom zakupnika, tada zakupodavac ima pravo na naknadu za umanjenu vrijednost istih, odnosno naknadu za njihovu vrijednost ako su isti od strane zakupnika uklonjeni.

U roku od šest mjeseci od raskida zakupnik ima pravo uzeti one dijelove objekata i uređaja koje je podigao, ukloniti trajne nasade te može tražiti naknadu neamortizirane vrijednosti trajnih nasada.

Ako se radi o miniranom poljoprivrednom zemljištu, tada vrijede sljedeća pravila. Kod zakupa takvog zemljišta zakupnina se umanjuje razmjerno troškovima razminiranja koje snosi zakupnik. Zakupnik je dužan takvo zemljište razminirati u roku od dvije godine od sklapanja ugovora o zakupu i ne može ga obrađivati dok ga ne razminira. Ako se u tom roku ne bi provelo razminiranje, tada je za to razdoblje dužan platiti zakupninu. Isto tako ako je poljoprivredno zemljište u vlasništvu države izvan funkcije ili je obraslo višegodišnjim raslinjem, tada je u slučaju sklapanja ugovora o zakupu zakupnik dužan takvo zemljište iskrčiti o vlastitom trošku, također u roku od dvije godine. Ako to ne bi učinio u tom roku, tada je zakupnik dužan zakupodavcu platiti zakupninu za te dvije godine.

Odredbom čl. 46. i 47. ZPZ-a propisan je zakup zajedničkih pašnjaka. Zajednički pašnjak je proizvodno-tehnološka cjelina poljoprivrednog zemljišta u vlasništvu države koje je u naravi pašnjak, livada, sjenokoša i neplodno zemljište namijenjeno zajedničkoj ispaši stoke i peradi, a može se nalaziti unutar ili izvan područja ekološke mreže. Zajednički pašnjak daje se u zakup fizičkoj ili pravnoj osobi putem javnog poziva na rok od pet godina. Agencija vodi Registara zajedničkih pašnjaka. Agencija donosi i odluku o dodjeli zakupa zajedničkog pašnjaka, te se na osnovi odluke o dodjeli zakupa sklapa ugovor o zakupu zajedničkog pašnjaka u pisanom obliku.

Poljoprivredno zemljište u vlasništvu države za koje nisu sklopljeni ugovor o zakupu i zakupu za ribnjake Agencija može sklopiti ugovor o privremenom korištenju s fizičkim ili pravnim osobama i to na zahtjev:

- posjednika kojima su istekli ugovori o zakupu poljoprivrednog zemljišta u vlasništvu države i koji su mirnom posjedu istoga,

- posjednicima koji su koristili poljoprivredno zemljište u vlasništvu države bez ugovora i u mirnom su posjedu istog.

Te su osobe dužne podmiriti sve obveze s osnove korištenja poljoprivrednog zemljišta, a sam ugovor o privremenom korištenju se sklapa na rok od pet godina, odnosno do sklapanja ugovora o zakupu ili zakupu za ribnjake, ili nekog drugog oblika raspolaganja poljoprivrednim zemljištem. 


\subsection{Zakup broda}

PZ sadrži određena pravila koja se odnose na zakup broda. Za pomorske brodove postoji upisnik trgovačkih brodova, upisnik ribarskih brodova i upisnik javnih brodova. Za brodove u gradnji postoji poseban upisnik brodova u gradnji, dok za jahte postoji poseban upisnik jahti. Jednako tako postoji i poseban upisnik za upisnik jahti u gradnji, zatim za plutajuće objekte, kao i plutajuće objekte u gradnji, kao i za nepomične odobalne objekte i nepomične odobalne objekte u gradnji. ${ }^{112}$

Zakup se upisuje u list C uloška glavne knjige upisnika, u koji se između ostalog upisuju stvarna prava kojima je pomorski objekt ili njegov dio opterećen, prava stečena na tim pravima, zakup broda ili drugog pomorskog objekta, brodarski ugovor na vrijeme za cijeli brod, pravo prvokupa, te druga ograničenja raspolaganja pomorskim objektom kojima je podvrgnut vlasnik opterećenog pomorskog objekta, zabrane opterećivanja i otuđivanja, te sve druge zabilježbe za koje nije propisano da se negdje drugdje upisuju. ${ }^{113}$

Sam zakup broda detaljnije je uređen odredbama čl. 658. do 672. PZ-a.

Tako su ugovorne strane ugovora o zakupu broda zakupodavatelj i zakupoprimatelj, pri čemu zakupodavatelj daje zakupoprimatelju brod na uporabu radi obavljanja plovidbene djelatnosti, a zakupoprimatelj se obvezuje zakupodavatelju plaćati zakupninu.

Ugovor o zakupu broda mora biti sklopljen u pisanoj formi, pa ugovor koji ne bi bio sklopljen u toj formi nema pravni učinak. Obveza je zakupodavatelja da preda zakupoprimatelju brod u takvu stanju da se može iskorištavati prema ugovorenoj ili uobičajenoj namjeni, s time da se u pravilu brod predaje bez posade. Takva odredba znači da je moguće dati u zakup brod i s posadom, pod pretpostavkom da to bude tako ugovoreno. Obveza je zakupoprimatelja da snosi troškove pogona broda, da održava brod za vrijeme trajanja ugovora i da nakon proteka ugovorenog razdoblja zakupa vrati brod u stanju i mjestu u kojem ga je primio. Kod toga zakupoprimatelj ne odgovara za redovno trošenje broda, ne snosi troškove popravka broda potrebnih za uklanjanje skrivenih mana broda, niti snosi štetu za gubitak broda zbog djelovanja više sile. Za štetu nastalu zbog mana broda koje brod čine nesposobnim ili smanjuju njegovu sposobnost za ugovoreno ili uobičajeno iskorištavanje, a koje su postojale u vrijeme predaje broda zakupoprimatelju, odgovara zakupodavatelj, osim ako dokaže da te mane nije mogao otkriti niti dužnom pažnjom.

Pravo je zakupoprimatelja da mijenja posadu, posada je inače dužna izvršavati naloge zakupoprimatelja.

U slučaju sumnje je li sklopljen ugovor o zakupu ili brodarski ugovor smatra se da je sklopljen brodarski ugovor.

Zakupnina se plaća mjesečno unaprijed, računajući od dana kada zakupnina počinje teći. Zakupodavatelju zakupnina ne pripada dok je zakupoprimatelj spriječen rabiti brod krivnjom zakupodavatelja ili zbog skrivene mane broda koja je postojala u trenutku predaje broda. 
Ako zakupoprimatelj ne plati zakupninu od dopjelosti, zakupodavatelj ima pravo odmah zatražiti naplatu zakupnine za cijelo ugovoreno razdoblje ili odustati od ugovora, a isto tako ima pravo i na naknadu štete.

Ugovor o zakupu broda može se sklopiti na određeno ili na neodređeno vrijeme, za jedno ili za više putovanja. Glede nadležnosti za suđenje u postupku povodom ugovora o zakupu broda u praksi je zauzeto shvaćanje „da spor o vraćanju akontacije iz ugovora o zakupu broda je spor iz zakupnih odnosa te je za suđenje u tom sporu isključivo mjesno nadležan sud na čijem se području vodi upisnik u kojem je brod upisan, te zbog isključive mjesne nadležnosti stranke ne mogu postići sporazum da im u tom sporu sudi neki drugi stvarno nadležan sud““. ${ }^{114}$

Ako je ugovor o zakupu sklopljen na određeno vrijeme, isti se može produljiti samo pisanim sporazumom, dok se ugovor o zakupu broda na neodređeno vrijeme može otkazati samo pisanim putem i to najkasnije tri mjeseca unaprijed. Iz navedene odredbe vidljivo je da je pisana forma bitan sastojak ugovora o zakupu broda.

Do prestanka ugovora o zakupu dolazi u slučaju propasti broda, njegove trajne nesposobnosti za iskorištavanje i u slučaju više sile koja onemogućuje iskorištavanje broda za vrijeme zakupa. Ugovor o zakupu sklopljen na određeno vrijeme prestaje istekom tog vremena. Zakupoprimatelj može odustati od ugovora o zakupu ako popravci broda koje snosi zakupodavatelj traju predugu ili se predviđa da će trajati predugo.

Propisane su i obveze ako zakupoprimatelj ne bi vratio zakupodavatelju brod nakon prestanka ugovora o zakupu. U tom slučaju zakupoprimatelj je dužan za prekoračeno vrijeme platiti zakupodavatelju naknadu u visini dvostruke zakupnine, a ako je zakupoprimatelj kriv za zakašnjenje u vraćanju broda, tada i isti odgovara i za svaku štetu iznad svote koja prelazi tu dvostruku zakupninu.

Određeno je da nagrada za spašavanje koje je obavljeno zakupljenim brodom za vrijeme trajanja zakupa pripada zakupoprimatelju.

Zakupoprimatelj ima pravo dati brod u podzakup samo na temelju pisanog pristanka zakupodavatelja. Kod toga u sudskoj praksi je zauzeto shvaćanje „da ugovor o podzakupu broda proizvodi pravne učinke samo uz zakupodavčev pisani pristanak." ${ }^{115}$

\subsection{Zakup zrakoplova}

Zakon o zračnom prometu ${ }^{116}$ ne sadrži posebne odredbe o ugovoru o zakupu zrakoplova, pa se na tu vrstu zakupa primjenjuju opće odredbe ZOO-a. U čl. 48. Zakona o zračnom prometu propisane su jedino obveze upisa zrakoplova u Registar zrakoplova. Tako je st. 1. navedenoga članka propisano da se inozemni zrakoplov koji je u zakup uzela fizička osoba s prebivalištem u Republici Hrvatskoj, odnosno pravna osoba sa sjedištem u Republici Hrvatskoj mora upisati u Registar najkasnije

114 VTSRH, Pž-982/06 od 28.XII.2006. (TS Zagreb P-2823/05 od 18.X.2005.) - www.ingbiro.com. 115 VTSRH, Pž-2410/06 od 18.II.2009. (TS Split P-1293/04 od 28.XI.2005.) - www.ingbiro.com. 116 Narodne novine, br. 69/09, 84/11, 54/13, 127/13, 92/14. 
po isteku 14 mjeseci od dana kad je takav zrakoplov dopremljen u Republiku Hrvatsku. Prema st. 2. na takav zrakoplov, neovisno o tome je li upisan u Registar ili ne, primjenjuju se odredbe ovoga Zakona koje se odnose na sigurnost zračnog prometa. Isto tako, prema st. 3. istoga članka, hrvatski zrakoplov koji je dan u zakup inozemnoj fizičkoj ili pravnoj osobi u svrhu obavljanja zračnog prometa u inozemstvu, može se upisati u inozemni registar, na zahtjev zakupoprimca (zakupnika), uz suglasnost vlasnika, ako je to predviđeno propisima te strane države. Ako se prema propisima strane države takav zrakoplov ne upisuje u inozemni registar, u Registru se takav zrakoplov vodi kao zrakoplov koji je dan u zakup u inozemstvu.

U sudskoj praksi je zauzeto shvaćanje da je „za suđenje u sporu iz ugovora o zakupu zrakoplova između fizičke i pravne osobe radi isplate zakupnine stvarno nadležan općinski sud". ${ }^{117}$

\subsection{Zakup cestovnog zemljišta}

Novi ZC konačno je definirao pravni status svih vrsta cesta u Republici Hrvatskoj. Prema odredbi čl. 3. st. 1. ZC-a javne ceste (autoceste, državne ceste, županijske ceste i lokalne ceste) su javno dobro u općoj uporabi u neotuđivom vlasništvu Republike Hrvatske. S druge strane nerazvrstane ceste su prema odredbi čl. 101. st. 1. ZC-a javno dobro u općoj uporabi u neotuđivom vlasništvu jedinice lokalne samouprave na čijem se području nalaze (grada ili općine).

Prema odredbi čl. 3. st. 4. ZC-a cestovno zemljište može se dati na korištenje radi obavljanja pratećih djelatnosti (ugostiteljstvo, trgovina, benzinske postaje i drugo) na način propisan tim Zakonom, dok se prema st. 8. istoga članka korištenje cestovnog zemljišta upisuje u zemljišnu knjigu sukladno odredbama o upisu zakupa prema propisima koji uređuju zemljišne knjige.

I kod nerazvrstanih cesta propisano je u čl. 101. st. 3. ZC-a da se dio nerazvrstane ceste namijenjene pješacima može dati u zakup sukladno posebnim propisima, ako se time ne ometa odvijanje prometa, sigurnost kretanja pješaka i održavanje nerazvrstane ceste. Sredstva ostvarena od zakupa cestovnog zemljišta koristit će se za financiranje održavanja nerazvrstanih cesta (čl. 108. ZC).

Koliko nam je poznato još uvijek veliki dio cestovnog zemljišta nije kao takav evidentiran u zemljišnoj knjizi i katastru, pa će se tek vidjeti kakvi će se sve problemi u praksi pojavljivati s time u vezi.

I kod zakupa cestovnog zemljišta primjenjujemo opća pravila o zakupu propisana ZOO-om, budući da ZC ne propisuje posebna pravila o zakupu cestovnog zemljišta. 


\section{ZAKUP KAO INSTITUT STVARNOG (ZEMLJIŠNOKNJIŽNOG) PRAVA}

\subsection{Općenito o knjižnim pravima}

Zemljišna knjiga je javni registar (javna knjiga) u koju se upisuju nekretnine, sva stvarna prava na nekretninama, neka obvezna prava za koja to propisuje bilo Zakon o zemljišnim knjigama ${ }^{118}$, bilo neki drugi propis, te pravne činjenice i osobni odnosi relevantni za pravni promet nekretnina.

Kada se govori o knjižnim pravima ${ }^{119},{ }^{120}$, tada se prije svega misli na stvarna prava koja se upisuju u zemljišnu knjigu, ali i na obvezna prava koja se mogu upisati u zemljišnu knjigu. U čl. 31. st. 1. ZZK-a propisano je da su predmet uknjižbe i predbilježbe ${ }^{121}$, kao knjižnih upisa, pravo vlasništva i ostala stvarna prava, pravo nazadkupa, prvokupa, najma, zakupa i koncesije, kao i ostala prava na nekretninama za koje je to posebnim zakonom dopuštenom. Ako bi knjižna prava bila ograničena, oročena ili uvjetovana tada se to ograničenje, rok ili uvjet u zemljišnoj knjizi upisuju zabilježbom.

Kako su i obvezna prava koja se upisuju u zemljišnu knjigu knjižna prava, to se ista u zemljišnu knjigu mogu upisati samo uknjižbom ili predbilježbom, ne i zabilježbom. Do uknjižbe će doći u slučaju ako isprava na temelju koje se zahtijeva upis ispunjava sve opće (čl. 43. i 44. ZZK) i posebne pretpostavke za uknjižbu (čl. 52., 53., 54. i 55. ZZK). Opće pretpostavke za upis u zemljišnu knjigu su postojanje valjane isprave sastavljene u obliku propisanom za valjanost isprave (čl. 43. ZZK), te da ista nema očitih nedostataka koji dovode u sumnju njihovu vjerodostojnost, pri čemu osobe protiv kojih i u čiju se korist upis zahtijeva moraju biti navedene tako da ne postoji opasnost da ih se zamijeni s drugim osobama (čl. 44. ZZK).

Posebne pretpostavke za uknjižbu su sljedeće:

- postojanje javne isprave ili privatne isprave na kojima je istinitost potpisa ovjerovljena na način propisan posebnih zakonom - čl. 52. ZZK,

- ako je privatna isprava potpisana po opunomoćeniku, nužno je da potpis opunomoćenika bude ovjerovljen sukladno čl. 52. ZZK, pri čemu se opunomoćenik mora iskazati posebnom punomoći (punomoći koja je izdana upravo za taj pravni posao) ili općom punomoći (punomoći koja je izdana

118 Narodne novine, br. 91/96, 68/98, 137/99, 114/01, 100/04, 107/07, 152/08, 126/10, 55/13, 60/13, dalje ZZK).

119 Josipović Tatjana, Zemljišnoknjižno pravo, Informator, Zagreb, str. 148-179.

120 Josipović Tatjana, Komentar Zakona o zemljišnim knjigama, Informator, Zagreb, str. 86-94.

121 Čl. 30. ZZK glasi: Knjižni su upisi uknjižba, predbilježba i zabilježba (st. 1.) Uknjižba je upis kojim se knjižna prava stječu, prenose, ograničuju ili prestaju bez posebnoga naknadnog opravdanja (st. 2.). Predbilježba je upis kojim se knjižna prava stječu, prenose, ograničuju ili prestaju samo pod uvjetom naknadnoga opravdanja i u opsegu u kojemu naknadno budu opravdana (st. 3.). Zabilježba je upis kojim se čine vidljivim mjerodavne okolnosti za koje je zakonom određeno da ih se može zabilježiti u zemljišnim knjigama. Zabilježbom se mogu osnivati određeni pravni učinci kad je to predviđeno zakonom (st. 4.). 
za određenu vrstu poslova), pri čemu opća punomoć u vrijeme podnošenja prijedloga ne smije biti starija od godine dana - čl. 53. ZZK-a,

- privatne isprave moraju sadržavati i točnu oznaku zemljišta ili prava glede kojega se uknjižba zahtijeva, te izričitu izjavu onoga čije se pravo ograničava, opterećuje, ukida ili prenosi na drugu osobu pristaje na uknjižbu (clausula intabulandi) - čl. 54. ZZK-a,

- javne isprave na temelju kojih se može dopustiti uknjižba su isprave koje su o pravnim poslovima sastavili za to nadležno tijelo ili javni bilježnik u granicama svoje ovlasti i u propisanom obliku, ako sadrže sve što se zahtijeva i za uknjižbu na temelju privatnih isprava, te odluke suda ili drugoga nadležnog tijela odnosno pred njima sklopljene nagodbe koje se prema propisima o ovrsi smatraju ovršnim ispravama prikladnim za upis prava u zemljišnu knjigu, ako sadrže točnu oznaku zemljišta ili prava na koji se upis odnosi.

Ukoliko isprava na temelju koje se traži upis udovoljava općim pretpostavkama za upis, a ne udovoljava posebnim pretpostavkama, tada se može dopustiti predbilježba (čl. 56. ZZK.). Sve to vrijedi i za obvezna prava kao knjižna prava, te se i ta prava mogu u zemljišnu knjigu upisati uknjižbom (bezuvjetni upis), odnosno predbilježbom (uvjetni upis ako se naknadno opravdaju). Primjerice ukoliko u ugovor o zakupu nekretnine nije dana dozvola za uknjižbu prava zakupa, tada bi se na temelju takvog ugovora mogla dopustiti predbilježba zakupa, koja bi se kasnije opravdala posebnom izjavom kojom bi zakupodavac dozvolio zakupniku uknjižbu zakupa u zemljišnu knjigu.

O dopustivosti predbilježbe govore čl. 56. do 59. ZZK-a. Naime, prema odredbi čl. 56. st. 1. ZZK-a ako isprava na temelju koje se zahtijeva upis ne odgovara posebnim pretpostavkama za uknjižbu (čl. 52., 53., 54. i 55. ZZK), ali ispunjava opće pretpostavke za zemljišnoknjižni upis (čl. 43. i 44. ZZK), na temelju te isprave dopustit će se predbilježba ako ju je moguće provesti. Stavkom 2. istog članka određeno je da ako je pristanak za uknjižbu dan uvjetno ili oročeno, da se tada isto tako može dopustiti predbilježba.

\subsection{Posebno o zakupu kao knjižnom pravu}

Obvezna prava koja se upisuju u zemljišnu knjigu su knjižna prava, jednako kao stvarna prava koja se upisuju u zemljišnu knjigu, pa se upis knjižnih prava u zemljišnu knjigu vrši uknjižbom ili predbilježbom.

No, ipak kada se govori o obveznim pravima kao knjižnim pravima ${ }^{122}$, postoje određene specifičnosti koje razlikuju obvezna prava kao knjižna prava u odnosu na ostala knjižna prava.

122 Vidi opširnije Damir Kontrec, Obvezna prava kao zemljišnoknjižna prava, u: Liber amicorum in honorem Vilim Gorenc, Pravni fakultet Sveučilišta u Rijeci, 2014. 
Obvezna prava uvijek nastaju na temelju pravnog posla, na temelju suglasnosti volja ugovornih strana. No, da bi došlo do upisa obveznog prava u zemljišnu knjigu, tada nije dovoljno da postoji samo volja ugovornih strana izražena u ugovoru, već mora postojati i pristanak knjižnog vlasnika da se određeno obvezno pravo upiše u zemljišnu knjigu kao teret nekretnine. Vlasnik nekretnine (zakupodavac, najmodavac, vlasnik nekretnine na kojoj se osniva koncesija) moraju u ispravi dati pristanak za uknjižbu - klauzulu intabulandi i jedino će se u tom slučaju moći obvezno pravo upisati uknjižbom u zemljišnu knjigu. Ako takve dozvole uknjižbe nema, tada se neće moći provesti bezuvjetni upis - uknjižba, već samo uvjetni upis obveznog prava kao knjižnog prava - predbilježba i u tom slučaju će zakupnik, najmoprimac, nositelj prava koncesije ... morati opravdati predbilježbu - ispraviti nedostatak koji postoji u ispravi, primjerice ovjeriti potpis onoga čije se pravo ograničava kod javnog bilježnika, dobiti ovjerenu klauzulu intabulandi, točno označiti nekretninu na kojoj se obvezno pravo mora upisati.

Za razliku od stvarnih prava koja se stječu na temelju pravnog posla i kom slučaju je upis u zemljišnu knjigu materijalnopravna pretpostavka za stjecanje stvarnih prava na temelju pravnog posla (modus), upis obveznih prava u zemljišnu knjigu nije materijalnopravna pretpostavka za stjecanje obveznih prava. Naime, obvezna se prava stječu na temelju pravnog posla, u času kada je pravni posao zaključen odnosno kada su stranke suglasile o bitnim sastojcima ugovora ${ }^{123}$.

No, i kod toga postoje određeni izuzetci. Naime, ako se radi o zakonskom pravu prvokupa, tada je takvo obvezno pravo stečeno već u trenutku kad su se za to ispunile zakonske pretpostavke ili takva prava postoje već temeljem samog zakona u korist određenih osoba. Tako primjerice prema Zakonu o zaštiti prirode ${ }^{124} \mathrm{u}$ slučaju prodaje nekretnina koje se nalaze u nacionalnim parkovima, strogog ili posebnog rezervata, postoji zakonsko pravo prvokupa u korist Republike Hrvatske, županije, opće odnosno Grada, pa to pravo neovisno o tome je li upisano u zemljišnu knjigu djeluje prema svima.

Ostala obvezna prava koja se ne stječu temeljem samog zakona, počinju djelovati apsolutno upisom u zemljišne knjige, a ne više samo između ugovornih strana (inter partes).

No, nakon što su obvezna prava upisana u zemljišnu knjigu za njih vrijede sva načela zemljišnoknjižnog prava. To znači da nakon što se obvezna prava upišu u zemljišnu knjigu, da se tada nitko ne može pozivati na to da nije znao, niti mogao znati da takva prava na nekretnini postoje.

Prema odredbi čl. 25. st. 1. ZZK-a u teretovnicu se upisuju stvarna prava kojima je opterećeno zemljišnoknjižno tijelo ili idealni dio nekoga suvlasnika, kao i prava stečena na tim pravima, pravo nazadkupa, prvokupa, najma i zakupa, te ona ograničenja raspolaganja zemljišnoknjižnim tijelom ili suvlasničkim dijelom kojima je podvrgnut svagdašnji vlasnik opterećenoga dobra. Prema st. 2. istoga članka u

123 Čl. 247. ZOO.

124 Narodne novine, br. 80/13 - čl. 165. U čl. 228. Zakona propisane su kaznene odredbe za one koji povrijede zakonsko pravo prvokupa. 
teretovnicu zemljišnoknjižnog tijela koje je opće dobro ili javno dobro u vlasništvu Republike Hrvatske ili jedinice lokalne uprave ili samouprave upisuje se koncesija prema odredbama za upis zakupa, ako što drugo nije posebno određeno.

Obvezna prava koja su kao knjižna prava upisana u zemljišnu knjigu prestaju isto tako tek kada su izbrisana iz zemljišne knjige.

U sudskoj praksi tako nailazimo na shvaćanje „da je upis uknjižbe prava zakupa na dijelu zemljišnoknjižnog tijela - jednoj od više samostalnih zgrada dopušten i bez promjene (otpisa u drugi uložak) njegova sastava ako je predmet zakupa (zgrada) precizno opisan te određen u zemljišnoknjižnoj ispravi (ugovor o zakupu) i ako je kao takav upisan u zemljišnoj knjizi kao sastavni dio tog složenog zemljišnoknjižnog uloška“. ${ }^{125}$

Kod upisa privremenog korištenja nekretnine zauzeto je shvaćanje „da pravno stanje nastalo na temelju ugovora i stambenog propisa koji više nije na snazi ne može se razriješiti izvan odredaba postojećeg ugovora i važećeg Zakona o najmu stanova, slijedom čega se upisi prava privremenoga korištenja nekretnina provode odgovarajućom primjenom odredaba o upisu prava najma odnosno zakupa““. ${ }^{126}$

Čini nam se potrebnim ukazati na značaj upisa zakupa (ali i drugih obveznih prava vezanih uz nekretnine) u zemljišnu knjigu. Naime, prema odredbi čl. 88. Ovršnog zakona ${ }^{127}$ izričito je propisano da ugovori o najmu odnosno zakupu nekretnine sklopljeni i upisani u zemljišnu knjigu prije stjecanja založnog prava ili prava na namirenje radi čijeg se ostvarenja ovrha traži ne prestaju prodajom nekretnine. No, ako ti ugovori nisu upisani u zemljišnu knjigu prije stjecanja založnoga prava ili prava na namirenje radi čijeg se ostvarenja ovrha traži prestaju pravomoćnošću rješenja o dosudi ${ }^{128}$ nekretnine kupcu. ${ }^{129}$ Najmoprimci i zakupci čiji

125 ŽS Bjelovar, Gž-2284/12-2 od 2.XI.2012. - www.ingbiro.

126 ŽS Rijeka, Gž-2176/05 od 7.XII.2007. - www.ingbiro.

127 Narodne novine, br. 112/12, 25/13, 93/14, dalje OZ.

128 Novelom OZ-a iz 2014. godine (Narodne novine, br. 93/14) potpuno je izmijenjen raniji čl. 103. OZ-a koji je govorio o rješenju o dosudi. Dosadašnji čl. 103. OZ-a je glasio: Pošto utvrdi da je udovoljeno uvjetima za održavanje ročišta za dražbu, sudac, odnosno javni bilježnik objavljuje da se pristupa dražbi (st. 1.). Dražba se zaključuje nakon proteka deset minuta neposredno poslije stavljanja najpovoljnije ponude (st. 2.). Nakon zaključenja dražbe sudac, odnosno javni bilježnik utvrđuje koji je ponuditelj ponudio najveću cijenu i da je ispunio uvjete da mu se dosudi nekretnina (st. 3.). O dosudi nekretnine sud donosi pisano rješenje (rješenje o dosudi) koje se objavljuje na oglasnoj ploči suda (st. 4.). Smatrat će se da je rješenje iz stavka 4. ovoga članka dostavljeno svim osobama kojima se dostavlja zaključak o prodaji te svim sudionicima u dražbi istekom trećega dana od dana njegova isticanja na oglasnoj ploči. Te osobe imaju pravo tražiti da im se u sudskoj pisarnici neposredno preda otpravak rješenja (st. 5.). U rješenju o dosudi sud će odrediti da će se nekretnina dosuditi i kupcima koji su ponudili nižu cijenu, redom prema veličini cijene koju su ponudili, ako kupci koji su ponudili veću cijenu ne polože kupovninu u roku koji im je određen ili koji će im biti određen. U tom slučaju sud će donijeti posebno rješenje o dosudi svakom sljedećem kupcu koji je ispunio uvjete da mu se nekretnina dosudi, u kojem slučaju će odrediti rok za polaganje kupovnine. Sud će u tom rješenju najprije oglasiti nevažećom dosudu kupcu koji je ponudio višu cijenu (st. 6.). O ročištu za prodaju vodi se zapisnik (st. 7.).

129 Vidi opširnije Gabrijela Mihelčić, Komentar Ovršnog zakona, Organizator, Pravo 85, Zagreb, 2015., str. 403-405. 
bi ugovori o zakupu ili najmu prestali pravomoćnošću rješenja o dosudi, nemaju zbog toga pravo tražiti naknadu štete u ovršnom postupku.

Zakonom o izmjenama i dopunama OZ-a iz 2014. godine Financijska agencija je dobila ovlasti za vođenje elektroničke dražbe nekretnina i pokretnina. Stoga su izmijenjana i pravila glede dosude nekretnine. Nova odredba čl. 103. OZ-a glasi:

(1) Elektronička javna dražba završava u trenutku koji je unaprijed određen u pozivu za sudjelovanje.

(2) Nakon završstka elektroničke javne dražbe Agencija je dužna bez odgode obavijestiti sud o provedenoj elektroničkoj javnoj dražbi, prikupljenim ponudama $i$ drugim potrebnim podacima, osim u slučaju iz članka 102. stavak 3. ovoga Zakona.

(3) Nakon primitka obavijesti iz stavka 2. ovoga članka sudac utvrđuje koji je kupac ponudio najveću cijenu $i$ da su ispunjene pretpostavke da mu se dosudi nekretnina.

(4) O dosudi nekretnine sud donosi pisano rješenje (rješenje o dosudi) koje se objavljuje na oglasnoj ploči suda i na mrežnim stranicama Agencije.

(5) Smatrat će se da je rješenje iz stavka 4. ovoga članka dostavljeno svim osobama kojima se dostavlja zaključak o prodaji te svim sudionicima u dražbi istekom trećega dana od dana njegova isticanja na oglasnoj ploči. Te osobe imaju pravo tražiti da im se u sudskoj pisarnici neposredno preda otpravak rješenja.

(6) U rješenju o dosudi sud će odrediti da će se nekretnina dosuditi i kupcima koji su ponudili nižu cijenu, redom prema veličini cijene koju su ponudili, ako kupci koji su ponudili veću cijenu ne polože kupovninu u roku koji im je određen ili koji će im biti određen. U tom slučaju sud će donijeti posebno rješenje o dosudi svakom sljedećeg kupcu koji je ispunio uvjete da mu se nekretnina dosudi, u kojem će odrediti rok za polaganje kupovnine. Sud će u tom rješenju najprije oglasiti nevažećom dosudu kupcu koji je ponudio višu cijenu.

Niti ZOO, niti ZZKPP ne sadrži posebne odredbe prema kojima bi postojala obveza da se ugovori o zakupu poslovnog prostora upisuju u zemljišnu knjigu, što je i razumljivo zbog slobodne ugovornih odnosa. Prema tome hoće li se ugovor o zakupu poslovnog prostora upisati u zemljišnu knjigu ili ne, ovisi prije svega o volji ugovornih strana te o tome hoće li se oni o tome dogovoriti. No, da bi se upis zakupa poslovnog prostora mogao izvršiti u zemljišnu knjigu, tada poslovni prostor mora biti, kao takav i upisan u zemljišnu knjigu.

\section{UMJESTO ZAKLJUČKA}

Zakup kao institut obveznog prava vrlo često se primjenjuje, pri čemu se i iz danog prikaza u ovom radu može zaključiti da za različite vrste predmeta zakupa vrijede različita pravila. Dobro sastavljen ugovor o zakupu, sastavljen zapisnik o primopredaji predmeta zakupa, utvrđivanje stanja u kojem se predmet zakupa po isteku ugovora o zakupu vraća zakupodavcu predstavlja preduvjet da bi eventualni sudski spor mogao izbjeći ili barem u znatnoj mjeri ubrzati. Jednako tako sklapanje ugovora o zakupu u formi javnobilježničkog akta ili solemnizirane isprave također 
ubrzava postupak, jer se izbjegava vođenje parnice, brže se dolazi do naplate zaostale zakupnine, a i predmeta zakupa se brže stavlja u pravni promet. Kada cijeli problem razmatramo s položaja suda, tada nam se čini da veliki broj sporova iz zakupnih odnosa nastaje upravo zbog nedovoljno preciznih, nedovoljno određenih ugovornih odredbi, odredbi koje kasnije daju mogućnost različitog tumačenja.

Čini nam se bitnim da kada se radi o zakupu nekretnina (bilo zemljišta, bilo poslovnih prostora) da bi tada trebalo nastojati da se ugovori o zakupu upišu u zemljišnu knjigu, jer će tada zemljišna knjiga prikazivati točno pravno stanje nekretnine. 


\section{Summary}

\section{LEASE AS INSTITUTE OF OBLIGATORY AND REAL RIGHTS}

The lease contract often occurs in practice and is one of the contract on the temporary transfer and use of things and goods. General regulation of the lease agreement stipulates by Obligations Act, on the other hand there are a number of special regulations governing contracts for the lease of specific types of things (agricultural land, office, ship). The article specifically points to the case law dealing with the institution of lease, especially talking about the lease as an institute real (land) rights.

Key words: lease, rent, lease contract, office, agricultural land, leased ship, the obligations of the lessor and the lessee, lease entry in the land register.

\section{Zusammenfassung}

\section{PACHT ALS SACHENRECHTS- UND SCHULDRECHTSINSTITUT}

Der Pachtvertrag kommt häufig in der Praxis vor und gehört zu den Verträgen über vorläufige Sachenübertragung und -Nutzung. Zusätzlich zur allgemeinen Regelung durch das Gesetz über Schuldverhältnisse besteht eine Reihe Sonderregelungen, die sich auf bestimmte Pachtvertragssachen beziehen (landwirtschaftliches Grundstück, Geschäftsraum, Boot). Der Akzent dieser Arbeit wird auf die Rechtsprechung, die sich mit diesem Institut beschäftigt gesetzt. Darüber hinaus, wird Pacht als ein Institut des Sachenrechts (Grundbuchsrechts) dargestellt.

Schlüsselwörter: Pacht, Miete, Pachtvertrag, Geschäftsraum, landwirtschaftliches Grundstück, Pacht eines Bootes, Pflichten von Verpächter und Pächter, Eintrag der Pacht ins Grundbuch. 


\section{Riassunto}

\section{LA LOCAZIONE QUALE ISTITUTO GIURIDICO DEI DIRITTI OBBLIGATORIO E REALE}

Il contratto di locazione sovente si presenta nella prassi e s'annovera tra $\mathrm{i}$ contratti volti al trasferimento temporaneo ed all'utilizzo del bene. La disciplina generale del contratto di locazione è dettata dalla legge sui rapporti di obbligazioni, mentre dall'altra parte esistono numerose leggi particolari, che disciplinano $\mathrm{i}$ contratti di locazione aventi ad oggetto particolari cose (fondo agrario, spazi commerciali, navi). Nel contributo si segnala in particolare modo la giurisprudenza che si occupa di tale istituto, in ispecie si tratta della locazione quale istituto giuridico del diritto reale (o meglio del diritto tavolare).

Parole chiave: locazione, affitto, locale ad uso commerciale, fondo agricolo, locazione di nave, obblighi del locatore e del conduttore, iscrizione della locazione nei libri fondiari. 